\title{
Simulating the Response of Red Bean Yield to Deficit Irrigation and Plant Densities by Applying the Rbean Model
}

\author{
Asemanrafat $\mathrm{M}^{1}$, Honar $\mathrm{T}^{2}$ \& Sepaskhah $\mathrm{AR}^{3}$ \\ ${ }^{1}$ Former Ph. D student of Department of Irrigation, Faculty of Agriculture, Shiraz University, Shiraz, Iran \\ ${ }^{2}$ Associate Professor of Department of Irrigation, Faculty of Agriculture, Shiraz University, Shiraz, Iran \\ ${ }^{3}$ Professor of Department of Irrigation, Faculty of Agriculture, Shiraz University, Shiraz, Iran \\ Correspondence: Maryam Asemanrafat, Former Ph. D student of Department of Irrigation, Faculty of \\ Agriculture, Shiraz University, Shiraz, Iran. Tel: 98-91-7484-7213, 9891-7112-1748, 98-71-322-8627. E-mail: \\ ma_aseman1360@yahoo.com, toorajhonar@gmail.com, sepas@shirazu.ac.ir
}

Received: October 6, 2016

Accepted: October 17, 2016

Online Published: July 10, 2017

doi:10.5539/mas.v11n8p19

URL: https://doi.org/10.5539/mas.v11n8p19

\begin{abstract}
The Rbean Model was simulated for deficit irrigation conditions and plant density by using experimental data collected over two consecutive years regarding the cultivation of red bean in the Badjgah region of Shiraz, Iran. A split plot arrangement was conducted in a complete randomized block design during two years. The foremost variable was four levels of irrigation including 60 (I4), 80 (I3), 100 (I2), and 120\% (I1) of the potential evapotranspiration under surface irrigation. A second variable was the spacing of $5 \mathrm{~cm}(\mathrm{~S} 1), 10 \mathrm{~cm}(\mathrm{~S} 2)$ and 15 $\mathrm{cm}$ (S3) between the plants within each row, and the distance of $30 \mathrm{~cm}$ between the rows. The experiment layout was conducted in three replications. Results of the first and second growing seasons of red bean (phaseolus vulgaris L. cv. Akhtar) were used for the calibration and validation of the Rbean model, respectively. According to the NRMSE and the $d$ value indices, the Rbean model presented a very good to fair estimation of actual evapotranspiration, soil water content, canopy cover, dry matter, crop yields and water productivity (WP). The advantage of this model is its simplicity and easy calibration in a range of climatic conditions for the cultivation of bean crop. The prediction of bean yield by this model can be used for a better irrigation management under different plant densities.
\end{abstract}

Keywords: red bean, simulation, Rbean model, crop yield

\section{Introduction}

The red bean is being consumed as a prevalent source of proteins, calories, fibers and minerals in many developing countries (Ramos et al, 1999; Singh et al, 1999). Plant distribution patterns and plant densities can practically affect the utilization of environmental resources. As a result, plant density is deemed vital factor when aspiring to higher grain yield (Board and Harvile, 1996).

Proper selection of crop varieties are regional-specific and require management since they have great effects on agricultural production projects. The pattern by which plants are spatially arranged within a given land area is a prime factor because an appropriate density of cultivated plants is a requirement for successful crop production systems. Planting pattern can be modified by changing the width of rows and the spacing between them. Hypothetically, the choice of narrow rows in plant spacing could be expected to increase the efficient use of resources and can also delay the onset of interplant competition. An optimum plant density for maximum economic yield would depend on the crop species, its variety and cultivation conditions. Accordingly, many cases of research have partly focused on the regulation of plant populations based on the availability of production factors and thus have investigated how plant density can affect the quantity and quality of yield, According to the research report (Kochaki and Banaianaval, 1994). By experience, the highest yields are achieved via optimum cultivation density which is in effect synonymous with the consistent distribution of plants. Furthermore, the structure of plant canopy is nonetheless of great importance with regard to measurable factors of the yield (Mohamadzadeh et al, 2011). In a relevant research report, Nazaralizadeh et al. (2012) found that the row spacing and plant density can affect the growth of safflower in a manner that could improve yield when closer row spacing was considered. Desired plant density can be devised based on a variety of criteria including 
plant characteristics, growth period, the time and method of planting, soil fertility, plant size, available soil water content, solar radiation, planting patterns and weeds status (Abbasi and Maleki, 2015). Where annual precipitation is insufficient, drought stress is a common limiting factor in crop growth and yield. It can profoundly reduce dry matter production, yield due to the fact that leaf area decreases as a result of drought. Drought also accelerates the senescence of leaf (Emam and Seghatoleslami, 2005). The red bean could be grown as a seed legume where rain-fed crop-rotations are applied with winter wheat. Such crop-rotations can increase the production diversity and improve the yield at each rotation (Emam et al, 2010).

There are hypothetical understandings that the red bean is susceptible to drought stress or water deficits. Nonetheless, the production of this crop on a global scale is often carried out where drought stress inevitably prevails, due to insufficient water supplies, sparse rainfall and/or inadequate irrigation (Machado and Durães, 2006). According to a report by FAO (2008), the global average yield of red beans is $568 \mathrm{~kg} / \mathrm{ha}$. Total area under cultivation in Iran is 115,833 ha and total production is 218858 tons, whereof $97.1 \%$ are cultivated under irrigated conditions and $2.9 \%$ are as dry farming or rain-fed. Due to limitations in the area of resourceful arable land and the common unfavorable climatic conditions, it would be an imperative to increase the yield per unit area, should agricultural commodities succeed to being produced in amounts worthy of trade (Azami et al, 2013). The determination of plant density is one of the most important criteria for cultivation management whereby high yield comes in the frontline for farmers to pursue. An appropriate irrigation regime needs to be planned for every region where rainfall is scarce. Also, due to the effects of plant density on plant establishment, discernible improvements in the quality and quantity of productions would require managements in weed control and overall product quality, besides outlining the most appropriate plant density. High harvesting index is a factor that considers the extents to which plant photosynthetic materials are dedicated to grain production and could accordingly guide towards higher economic yield. This index is an important criterion for the management of plant tolerance to water stress. Researchers have shown that water stress not only reduces grain yield, but also limits the total amount of biomass production and largely affects the harvest index (Mohammadzadeh et al, 2011).

Information and data are vital criteria for agricultural management decision making, and they are increasing in volume at a high rate in many areas due to increased demands for agricultural products. Limitations on usable land, water, and other natural resources also contribute to the demand for more precise decision making tests in agriculture. The outset of new data through traditional agronomic research methods is not sufficient enough to meet these rising demands.

Crop models can be of a benefit for a variety of functions; primarily, crop models can interpret experimental results and work as agronomic research some tools for the analysis of research knowledge. Lengthy and expensive field experiments, particularly those that exploit numerous treatments, can be pre-evaluated via a well-proven model in order to further render accuracy in the field tests and to reduce their overall costs (Whisler et al, 1986). Another application of crop models is when researchers employ them to support actual decisions for the management of systems. Optimum management practices, whether they are strategic, including planting date, cultivar selection, fertilization, or water and pesticides application can be experimented through valid models so as to conclude the most sensible of seasonal or within-season decisions (Boote et al, 1996). The process of planning and policy analysis can be improved by better methods of modeling as well. Facilitating the application of crop models in a systems approach that stems from agronomic research requires the initial development as being generated by scientific guidelines to integrate knowledge about soil, climate, crops, and farm management. All of this is to conclude with better decisions about transferring production technology from one location to another in places that host varied soils and climates in comparison to each other (Uehara and Tsuji, 1998).

The Food and Agriculture Organization (FAO) developed a model for water productivity, called the AquaCrop (Raes et al., 2009; Steduto et al, 2009). AquaCrop is a crop-model developed by the Food and Agriculture Organization (FAO) which simulates biomass and yield response against the consumption of water where different soil, water and climatic conditions prevail (Steduto, 2009). Aqua crop model could not simulate accurately at deficit irrigation for some crops and for some regions. The objective of this research were: 1) To develop a simulation model (Rbean) for red bean yield in different plant densities and irrigation regimes 2) To calibrate and validate the Rbean model with an experimental data.

\section{Method}

\subsection{Field Experiment}

\subsubsection{Field Data}

The data of this investigation were obtained from two years experiment in 2013 and 2014 that were conducted at 
Experimental Station of Agricultural College, Shiraz University located in Badjgah region at $29^{\circ} 56^{\prime} \mathrm{N}, 52^{\circ} 02^{\prime}$ $\mathrm{E}$ and $1810 \mathrm{~m}$ above the mean sea level, in southwest of Iran with a semi-arid climate.

The predominant soil is characterized as silty clay loam (Table 1). Chemical analysis of the soil indicated that the amount of fertilizer required for cultivating agronomic crops in the research field is $250 \mathrm{Kg} / \mathrm{ha}$ of urea fertilizer and $250 \mathrm{~kg} / \mathrm{ha}$ of superphosphate that can be applied to the soil before sowing. Chemical analysis of the irrigation water is shown in Table 2.

Red beans (phaseolus vulgaris L. cv. Akhtar) were planted by a plant density of 66,33 and 22 plant $/ \mathrm{m}^{2}$ on May 26, 2013 and on May 18, 2014 in the first and second years, respectively in six rows with $30 \mathrm{~cm}$ spacing between the rows and in a soil depth of $5 \mathrm{~cm}$ in each plot.

Table 1. Physico-chemical properties of the soil at the experimental site

\begin{tabular}{|c|c|c|c|}
\hline \multirow{2}{*}{ Characteristic } & \multicolumn{3}{|c|}{ Soil depth $(\mathrm{cm})$} \\
\hline & $0-15$ & $15-30$ & $30-60$ \\
\hline Field capacity (v/v, \%) & 0.302 & 0.322 & 0.336 \\
\hline Permanent wilting point (v/v, \%) & 0.196 & 0.198 & 0.208 \\
\hline$\%$ Sand & 11 & 10 & 16 \\
\hline$\%$ Silt & 56 & 51 & 50 \\
\hline$\%$ Clay & 33 & 39 & 34 \\
\hline Texture & SCL & SCL & $\mathrm{SCL}$ \\
\hline $\mathrm{EC}\left(\mathrm{dS} \mathrm{m} \mathrm{m}^{-1}\right)$ & 0.74 & 0.51 & 0.49 \\
\hline $\mathrm{Cl}^{-}\left(\right.$meq $\left.1^{-1}\right)$ & 5.31 & 3.05 & 2.9 \\
\hline $\mathrm{Na}^{+}\left(\right.$meq $\left.1^{-1}\right)$ & 3.29 & 1.97 & 1.91 \\
\hline $\mathrm{Ca}^{2+}\left(\right.$ meq $\left.1^{-1}\right)$ & 5.43 & 4.16 & 4.07 \\
\hline $\mathrm{Mg}^{2+}\left(\right.$ meq $\left.\mathrm{l}^{-1}\right)$ & 3.5 & 2.88 & 2.84 \\
\hline
\end{tabular}

Table 2. Chemical analysis of irrigation water used in the experiment (average of two years)

\begin{tabular}{|c|c|}
\hline Characteristic & Irrigation water \\
\hline $\mathrm{EC}\left(\mathrm{dS} \mathrm{m^{-1 } )}\right.$ & 0.45 \\
\hline $\mathrm{pH}$ & 7.58 \\
\hline $\mathrm{Cl}^{-}\left(\right.$meq $\left.1^{-1}\right)$ & 0.8 \\
\hline $\mathrm{Na}^{+}\left(\right.$meq $\left.1^{-1}\right)$ & 0.7 \\
\hline $\mathrm{Ca}^{2+}\left(\mathrm{meq}^{-1}\right)$ & 4 \\
\hline $\mathrm{Mg}^{2+}\left(\right.$ meq $\left.1^{-1}\right)$ & 3 \\
\hline $\mathrm{HCO}_{3}-\left(\right.$ meq $\left.1^{-1}\right)$ & 4 \\
\hline $\mathrm{SO}_{4}{ }^{2-}\left(\mathrm{meq} \mathrm{l}^{-1}\right)$ & 2.5 \\
\hline
\end{tabular}

Reference evapotranspiration (ETo) was calculated using modified Penman-Monteith equation for semi-arid environments in the study area (Razzaghi and Sepaskhah, 2012). Meteorological data were obtained from standard weather stations at the Agricultural College, located near the experimental field.

To ensure uniform germination and emergence, equal amounts of irrigation water were applied to all treatments in the initial stage. The experimental plots were irrigated by the furrow irrigation method by an applied efficiency of $80 \%$. Before each irrigation event, the irrigation water requirements were estimated by multiplying the reference evapotranspiration values (ETo) at kc. ET of the red bean plant in the full irrigation treatment was calculated by using the modified Penman-FAO equation for semi-arid environments in the studied area (Razzaghi and Sepaskhah, 2012). In the first year, the kc of the red bean plant was obtained from the (FAO) of the United Nation (Allen et al, 1998) but in the second year the kc was derived from the soil water balance obtained in the first year. Irrigation water was applied every other week according to the four irrigation treatments: 1.2, $1,0.8$ and 0.6 multiplications of the crop's potential evapotranspiration of red bean. The presence of a deep groundwater table enabled free drainage conditions. Each experimental plot was 6 meters long and 3 meters wide.

A split plot arrangement was conducted in complete randomized block design during two years. The foremost 
variable was four levels of irrigation: $60,80,100,120 \%$ of the crop potential evapotranspiration under surface irrigation. The second variable was to have spaces of $5 \mathrm{~cm}(\mathrm{~S} 1), 10 \mathrm{~cm}(\mathrm{~S} 2)$ or $15 \mathrm{~cm}$ (S3) between the plants within each row, and the spacing of $30 \mathrm{~cm}$ between the rows, in three replications (Figure.1). Soil water content at 0-0.2, 0.2-0.4 and 0.4-0.6 m depths was measured by the gravimetric method before each irrigation event. Irrigation was carried out every 7 days.

\begin{tabular}{|c|c|c|}
\hline I4S2R3 & I1S1R1 & I4S2R2 \\
\hline I4S1R3 & I1S2R1 & I4S1R2 \\
\hline I4S3R3 & I1S3R1 & I4S3R2 \\
\hline I1S2R3 & I2S2R1 & I1S3R2 \\
\hline I1S1R3 & I2S1R1 & I1S2R2 \\
\hline I1S3R3 & I2S3R1 & I1S1R2 \\
\hline I2S2R3 & I3S3R1 & I2S2R2 \\
\hline I2S1R3 & I3S2R1 & I2S1R2 \\
\hline I2S3R3 & I3S1R1 & I2S3R2 \\
\hline I3S3R3 & I4S2R1 & I3S2R2 \\
\hline I3S2R3 & I4S1R1 & I3S3R2 \\
\hline I3S1R3 & I4S3R1 & I3S3R2 \\
\hline
\end{tabular}

Figure 1. Layout of experimental field at different irrigation strategies and plant density

The actual crop evapotranspiration for the time intervals between measurements of soil water content was estimated by the water balance procedure as follows:

$$
\mathrm{ET}=\mathrm{I}+\mathrm{P}-\mathrm{D}_{\mathrm{p}} \pm \Delta \mathrm{S}
$$

Where $I$ is the irrigation depth $(\mathrm{mm}), \mathrm{P}$ is the precipitation $(\mathrm{mm}), \mathrm{D}_{\mathrm{p}}$ is the deep percolation $(\mathrm{mm})$ from the bottom of root zone and $\Delta \mathrm{S}$ is the variation of soil water content in root by depth (mm). Water productivity (WP, $\mathrm{kg} / \mathrm{m}^{3}$ ) is a quantitative term used to define the relationship between the amount of crop produced and total applied water. It can be calculated as follows: (Sinclair et al. 1984):

$$
\mathrm{WP}=\text { Grain yield }(\mathrm{kg} / \mathrm{ha}) / \text { Total applied water }\left(\mathrm{m}^{3} / \mathrm{ha}\right)
$$

\subsubsection{Plant Measurements and Calculations}

During the period of red bean plant growth, several characteristics were measured at certain points after sowing, and the following numbers represent the serial of days after sowing, the days on which measurements were done on the corresponding trait [20 (vegetative), 50 (flowering), 68 (flowering \& pod formation) and 71 (pod formation \& pod fill), 85 (senescence) in 2013 and, for 2014, measurements were made on the following days after sowing: 22 (vegetative), 55 (flowering), 70 (pod formation \& pod fill) and 87 (senescence) in 2014]. The values of leaf area index (LAI) and aboveground dry matter (DM, $\mathrm{kg} \mathrm{ha}^{-1}$ ) were measured in intervals of 14 days. Five plants were selected randomly and the area of leaves was measured using the Delta-T-WinDias-Leaf Area meter for each sample before drying. Finally, LAI of the sample was determined as green leaf area per unit ground surface area. The canopy was sampled at area of $2 \mathrm{~m}^{2}$ from different experimental plots on harvest day. They were dried at $80{ }^{\circ} \mathrm{C}$ in an oven, and the dry matter of the shoot $\left(\mathrm{kg} \mathrm{ha}^{-1}\right)$ and grain yield $\left(\mathrm{kg} \mathrm{ha}^{-1}\right)$ were measured. Canopy cover of the plant was measured over a monthly interval by using image processing in Matlab software, based on photos taken vertically and digital photos from the red bean plots. The photos were taken from a distance of 1.5 meters from the ground surface.

\subsection{Model Description}

\subsubsection{Model Growth-Engine and Structural Components}

Biomass calculations were based on the concept of biomass water productivity, which is the amount of biomass produced per unit of consumed water (Steduto et al, 2007). According to this approach, the transpiration (T) is normalized with both the reference ET $\left(\mathrm{ET}_{\mathrm{o}}\right)$ (Equation 3).

$$
W P_{b}^{* *}=\frac{\text { Biomass }}{T^{* *}}=\frac{\text { Biomass }}{\sum \frac{T}{E T_{o}}}
$$


Where $\mathrm{WP}_{\mathrm{b}}{ }^{* *}$ is the normalized biomass water productivity, Biomass is the above-ground biomass $\left(\mathrm{kg} \mathrm{ha}^{-1}\right)$ in the season, $\mathrm{T}^{* *}$ is the normalized seasonal transpiration, $\mathrm{T}$ is the daily transpiration $\left(\mathrm{mm} \mathrm{d}^{-1}\right)$, and $\mathrm{ET}_{\mathrm{o}}$ is the daily reference evapotranspiration $\left(\mathrm{mm} \mathrm{d}^{-1}\right)$. The biomass water productivity $\left(\mathrm{WP}_{\mathrm{b}}\right)$ is the biomass produced per unit of transpired water. The $\mathrm{WP}_{\mathrm{b}}{ }^{* *}$ is the biomass produced per unit of normalized $\mathrm{T}$ (Steduto et al, 2006; Steduto et al, 2009).

\subsubsection{Potential Canopy Cover $\left(\mathrm{CC}_{\mathrm{p}}\right)$}

The Rbean model does not simulate leaf area index. Instead, foliage development is expressed as potential green canopy cover $\left(\mathrm{CC}_{\mathrm{p}}\right)$, the fraction of the soil surface covered by the canopy for full irrigation treatments. The value $\mathrm{CC}_{\mathrm{p}}$ varies between 0 (before emergence) to a maximum $\left(\mathrm{CC}_{\mathrm{xp}}\right)$ which can reach $100 \%$ depending on crop type and planting density. The potential canopy is a decisive feature in the Rbean model. Its expansion, aging, conductance and senescence are the main determinants for the amount of potential water transpired, which in turn determines the amount of produced potential biomass (Steduto et al, 2009). The canopy development for non-limiting conditions is modeled using three parameters: the initial canopy-cover after emergence (CCo), the maximum potential canopy-cover which can be reached $\left(\mathrm{CC}_{\mathrm{xp}}\right)$, and the potential canopy growth coefficient $\left(\mathrm{CGC}_{\mathrm{p}}\right)$. First-order kinetics-equations are used for the simulation of potential canopy development (Bradford and Hsiao, 1982; Hsiao, 1982). Upon the start of canopy senescence, the decline in $\mathrm{CC}_{\mathrm{p}}$ is simulated with a potential canopy decline coefficient $\left(\mathrm{CDC}_{\mathrm{p}}\right)$.

\subsubsection{Calibration of Model for Red Bean}

Different plant density applications in furrow irrigation are considered as a strategy that can be used for increasing the effect of irrigation water on crops growth and yield. Therefore, by considering the red bean as a crop that is susceptible to low amounts of irrigation water under different densities of cultivation, the red bean response can be assessed and predicted by using the Rbean model. The effects of three plant density $(66,33$ and 22 plant $\mathrm{m}^{-2}$ ) was considered on coefficients of the $\mathrm{CC}_{\mathrm{o}}, \mathrm{CGC}_{\mathrm{p}}, \mathrm{CC}_{\mathrm{Xp}}, \mathrm{CDC}_{\mathrm{p}}$ for determine potential canopy cover function, These coefficients that are derived based on the first year measured data and their related equations are shown in Table 3 for different treatments.

Table 3. The values of the calibration coefficients in the simulated model for different cultivation densities

\begin{tabular}{clll}
\hline Plant density & $66 \mathrm{plant} \mathrm{m}^{-2}$ & $33 \mathrm{plant}^{-2}$ & $22 \mathrm{plant} \mathrm{m}^{-2}$ \\
\hline Calibration coefficient in the model & \multicolumn{2}{l}{ Value of coefficient } & \\
\hline $\mathrm{CC}_{\mathrm{O}}$ & 0.033 & 0.016 & 0.011 \\
$\mathrm{CGC}_{\mathrm{p}}$ & $0.45 \% / \mathrm{GDD}$ & $0.50 \% / \mathrm{GDD}$ & $0.60 \% / \mathrm{GDD}$ \\
$\mathrm{CC}_{\mathrm{Xp}}$ & 0.85 & 0.74 & 0.55 \\
$\mathrm{CDC}_{\mathrm{p}}$ & $0.11 \% / \mathrm{GDD}$ & $0.09 \% / \mathrm{GDD}$ & $0.06 \% / \mathrm{GDD}$ \\
$\mathrm{WP}^{*}$ & $16 \mathrm{~g} / \mathrm{m}^{2}$ & $16 \mathrm{~g} / \mathrm{m}^{2}$ & $16 \mathrm{~g} / \mathrm{m}^{2}$ \\
\hline
\end{tabular}

There are relationships between the values of $\mathrm{CC}_{\mathrm{O}}, \mathrm{CGC}_{\mathrm{p}}, \mathrm{CC}_{\mathrm{Xp}}, \mathrm{CDC}_{\mathrm{p}}$ and plant density under full irrigation (I1 and I2) for the years 2014. Accordingly, the following equations are obtained from the regression between $\mathrm{CC}_{\mathrm{O}}$, $\mathrm{CGC}_{\mathrm{p}}, \mathrm{CC}_{\mathrm{Xp}}, \mathrm{CDC}_{\mathrm{p}}$ and with regard to the plant density for I1 and $\mathrm{I} 2$ irrigation treatments during the growing season that is shown in equation $4,5,6$ and 7 respectively.

$$
\begin{aligned}
& \mathrm{CCO}=-0.0000698+0.0005 \mathrm{den}(4) \\
& \mathrm{CGC}_{\mathrm{p}}=0.00925-0.0001837 \mathrm{den}+0.0000016875 \mathrm{den}^{2} \mathrm{R}^{2}=0.99, \mathrm{SE}=0.00016, \mathrm{n}=12, \mathrm{p}<0.001 \quad(5) \\
& \mathrm{CC}_{\mathrm{Xp}}=-0.05996+0.034535 \mathrm{den}-0.00031 \mathrm{den}^{2} \mathrm{R}^{2}=0.98, \mathrm{SE}=0.00006, \mathrm{n}=12, \mathrm{p}<0.001 \quad(6) \\
& \mathrm{CDC}_{\mathrm{p}}=-0.000264+0.0000548 \mathrm{den}-0.000000515 \mathrm{den}^{2} \mathrm{R}^{2}=0.98, \mathrm{SE}=0.0004, \mathrm{n}=12, \mathrm{p}<0.001
\end{aligned}
$$

Where den is the density (plants per square meter).

\subsubsection{Potential Transpiration}

Potential crop transpiration (T) is calculated by multiplying the ETo (or the evaporating power of the atmosphere) by the crop coefficient $\mathrm{Kc}_{\mathrm{Tr}}$ (Eq. 8). The ETo generates a better result when calculated by the modified Penmane-Monteith equation as specified by the FAO 56 (Razzaghi and Sepaskhah, 2012) and then given to the model as an input driving variable. The crop transpiration coefficient $\mathrm{Kc}_{\mathrm{Tr}}$ is proportional to $\mathrm{CC}_{\mathrm{p}}$, (Villalobos and Fereres, 1990; Steduto et al, 2009). The maximum of the proportional factor $\left(\mathrm{Kc}_{\mathrm{T}, \mathrm{x}}\right)$ varies between 1.0 and 1.2 for various common agricultural crops. 


$$
\begin{gathered}
\mathrm{T}_{\mathrm{p}}=\left(\mathrm{Kc}_{\mathrm{Tr}, \mathrm{x}} \mathrm{CC}_{\mathrm{p}}{ }^{*}\right) \text { ETo } \\
1-\mathrm{CC}_{\mathrm{p}}{ }^{*}=1-1.72 \mathrm{CC}_{\mathrm{p}}+\mathrm{CC}_{\mathrm{p}}{ }^{2}-0.3 \mathrm{CC}_{\mathrm{p}}{ }^{3}
\end{gathered}
$$

Where ETo is the amount of evaporation used as a reference, the $\mathrm{Kc}_{\mathrm{T}, \mathrm{x}}$ is the crop coefficient, $\mathrm{CC}_{\mathrm{p}} *$ is the adjusted potential green canopy-cover.

\subsubsection{Potential Biomass}

Potential biomass were calculated with Equation 10 for each days (Steduto et al, 2007):

$$
\text { Biomass }_{\mathrm{p}}=\mathrm{WP}_{\mathrm{b}}^{* *} \sum \frac{\mathrm{T}_{\mathrm{p}}}{\mathrm{ET}_{\mathrm{o}}}
$$

Where biomass $s_{\mathrm{p}}$ is the potential biomass $\left(\mathrm{g} \mathrm{m}^{-2}\right), \mathrm{WP}_{\mathrm{b}} * *$ is the normalized biomass water productivity, $\mathrm{T}_{\mathrm{p}}$ is the daily potential transpiration $\left(\mathrm{mm} \mathrm{d}^{-1}\right)$, and $\mathrm{ET}_{\mathrm{o}}$ is the daily reference evapotranspiration $\left(\mathrm{mm} \mathrm{d}^{-1}\right)$. The $\mathrm{WP}_{\mathrm{b}}{ }^{* *}$ is the biomass produced per unit of normalized T (Steduto et al, 2006; Steduto et al, 2009).

\subsubsection{Actual Biomass (Biomass ${ }_{a}$ ) for Deficit Irrigation Condition}

In order to minimize the number of inputs required, the biomass ratio was selected to evaluate the relevant effects of deficit irrigation. In this research, potential biomass is defined as the biomass that occurs when transpiration is never restricted, even when the soil is experiencing water stress throughout the growing season. In contrast to a traditional transpiration ratio of $T_{a} / T_{p}$, the biomass ratio is equivalent to the normalized transpiration ratio, as detailed in Equation. (Equation 11, 12 and 13).

$$
\begin{gathered}
\frac{\text { Biomass }_{\mathrm{a}}}{\text { Biomass }_{\mathrm{p}}}=\frac{\mathrm{WP}^{* *} \sum \frac{\mathrm{T}_{\mathrm{a}}}{\mathrm{ET}_{\mathrm{o}}}}{\mathrm{WP}^{* *} \sum \frac{\mathrm{T}_{\mathrm{p}}}{\mathrm{ET}_{\mathrm{o}}}}=\frac{\sum \frac{\mathrm{T}_{\mathrm{a}}}{\mathrm{ET}_{\mathrm{o}}}}{\sum \frac{\mathrm{T}_{\mathrm{p}}}{\mathrm{ET}_{\mathrm{o}}}} \\
\frac{\text { Biomass }_{\mathrm{a}}}{\text { Biomass }_{\mathrm{p}}}=\frac{\sum \frac{\mathrm{T}_{\mathrm{a}}}{\mathrm{ET}_{\mathrm{o}}}}{\sum \frac{\mathrm{T}_{\mathrm{p}}}{\mathrm{ET}_{\mathrm{o}}}}=\frac{\sum \frac{\mathrm{K}_{\mathrm{s}} \mathrm{K}_{\mathrm{cb}} \mathrm{ET}_{\mathrm{o}}}{\mathrm{ET}_{\mathrm{o}}}}{\sum \frac{\mathrm{K}_{\mathrm{cb}} \mathrm{ET}_{\mathrm{o}}}{\mathrm{ET}_{\mathrm{o}}}}=\frac{\sum \mathrm{K}_{\mathrm{s}} \mathrm{K}_{\mathrm{cb}}}{\sum \mathrm{K}_{\mathrm{cb}}} \\
\text { Biomass }_{\mathrm{a}}=\text { Biomass }_{\mathrm{p}} \frac{\sum \mathrm{K}_{\mathrm{s}} \mathrm{K}_{\mathrm{cb}}}{\sum \mathrm{K}_{\mathrm{cb}}}
\end{gathered}
$$

This equation for Biomass ratio only requires daily values of the basal crop coefficient $\left(\mathrm{K}_{\mathrm{cb}}\right)$ and water stress coefficient $\left(\mathrm{K}_{\mathrm{s}}\right)$, allowing the biomass ratio to be calculated at the end of the simulated growing season (Heeren et al, 2011).

\subsubsection{Yield}

Crop yield (Y) is calculated as the product of final biomass (B) and a harvest index (HI). The actual HI is obtained by adjusting, during simulation, the reference harvest index $\left(\mathrm{HI}_{\mathrm{o}}\right)$ with an adjustment factor $\left(\mathrm{f}_{\mathrm{HI}}\right)$ for stress effects. HIo is the fraction of B that is harvestable as observed under non-stress conditions and is a cultivar-specific parameter. $\mathrm{Y}$ is calculated as:

$$
\mathrm{Y}=\mathrm{f}_{\mathrm{HI}} \mathrm{HI} \mathrm{B}
$$

$\mathrm{f}_{\mathrm{HI}}$ depends on the timing and extent of water or temperature stress during the crop cycle.

\subsection{Input and Output Files for Simulated Model}

This model has an input file of notepad format and contains meteorological information including maximum and minimum daily temperature $\left({ }^{\circ} \mathrm{C}\right)$, reference evapotranspiration $(\mathrm{mm})$ and amount of precipitation and irrigation depth (mm). In addition, variables that function in the model include the initial soil water content, soil water contents at FC, PWP and the saturation condition, information about plant characteristics and some parameters for calculating stress coefficients. Also, plant density should be chosen by the user. The model output file 
contained fourteen notepad files including the daily root depth $(\mathrm{cm})$, basal crop coefficient $\left(\mathrm{K}_{\mathrm{cb}}\right)$, soil evaporation coefficient $\left(\mathrm{K}_{\mathrm{e}}\right)$ and daily crop evapotranspiration $\left(\mathrm{mm} \mathrm{d}^{-1}\right)$, deep percolation $(\mathrm{mm})$, volumetric soil water content (\%) in each quarter of root zone and mean volumetric soil water content (\%), soil water stress coefficient, daily actual evapotranspiration $\left(\mathrm{mm} \mathrm{d}^{-1}\right)$, canopy cover, daily soil surface evaporation $\left(\mathrm{mm} \mathrm{d}^{-1}\right)$, transpiration $\left(\mathrm{mm} \mathrm{d}^{-1}\right)$, daily and seasonal dry matter $\left(\mathrm{kg} \mathrm{ha}^{-1}\right)$, seasonal red bean yields $\left(\mathrm{kg} \mathrm{ha}^{-1}\right)$ and water productivity (WP).

2.4 Statistical Analysis

To evaluate the predicted results, the Normalized Root Mean Square Error (NRMSE) and the index of agreement (d) were calculated by the following equations:

$$
\begin{gathered}
\text { NRMSE }=\frac{\sqrt{\sum_{i=1}^{n}\left(p_{i}-o_{i}\right)^{2} / n}}{\bar{o}} \\
d=1-\frac{\sum_{i=1}^{n}\left(p_{i}-o_{i}\right)^{2}}{\sum_{i=1}^{n}\left(\left|p_{i}-\bar{o}\right|+\left|o_{i}-\bar{o}\right|\right)^{2}}
\end{gathered}
$$

Where $\mathrm{Pi}$ is the predicted value and Oi is the measured value of each parameter, the $\mathrm{n}$ is the number of measurements and $\mathrm{O}$ is the mean value of the measured factors. The values of NRMSE and $\mathrm{d}$ vary between 0.0 and 1.0. When the value of NRMSE is closer to 0.0 and $\mathrm{d}$ is closer to 1.0 , the model is more accurate. The simulation is considered excellent if the NRMSE value is less than $10 \%$, good if the NRMSE is between $10 \%$ and $20 \%$, fair if NRMSE is between $20 \%$ and $30 \%$ and poor if the NRMSE is greater than $30 \%$ (Jamieson et al, 1991).

\section{Discussion}

Experimental results of the first and second growing seasons were applied to calibrate and validate the simulated Rbean model, respectively. The Rbean model was able to simulate red bean growth and yield under deficit irrigation and different densities of cultivation. The flowchart of the Rbean model is shown in Figure. 2.

\subsection{Model Calibration}

\subsubsection{Evapotranspiration}

The relationship between the simulated and measured values of seasonal actual evapotranspiration (ETa) for the first year, known as the calibrated stage for different treatments during the growing season in 2013, are shown in Figure. 3. The slopes and intercepts of the linear relationships between the measured and simulated ETa were analyzed statistically. The intercept was not significant for the ETa relationship; therefore, the regression equation was forced to pass the origin of coordinates. The values of NRMSE and d showed that the calibrated Rbean model could estimate ETa with high accuracy (Table 4). Calibrations of actual evapotranspiration (ETa) for I4 irrigation levels, serving as samples in the first year, are shown in Figure.4. Because of the measured data was weekly mean and simulate data was daily cause to different between measured and simulated data. 


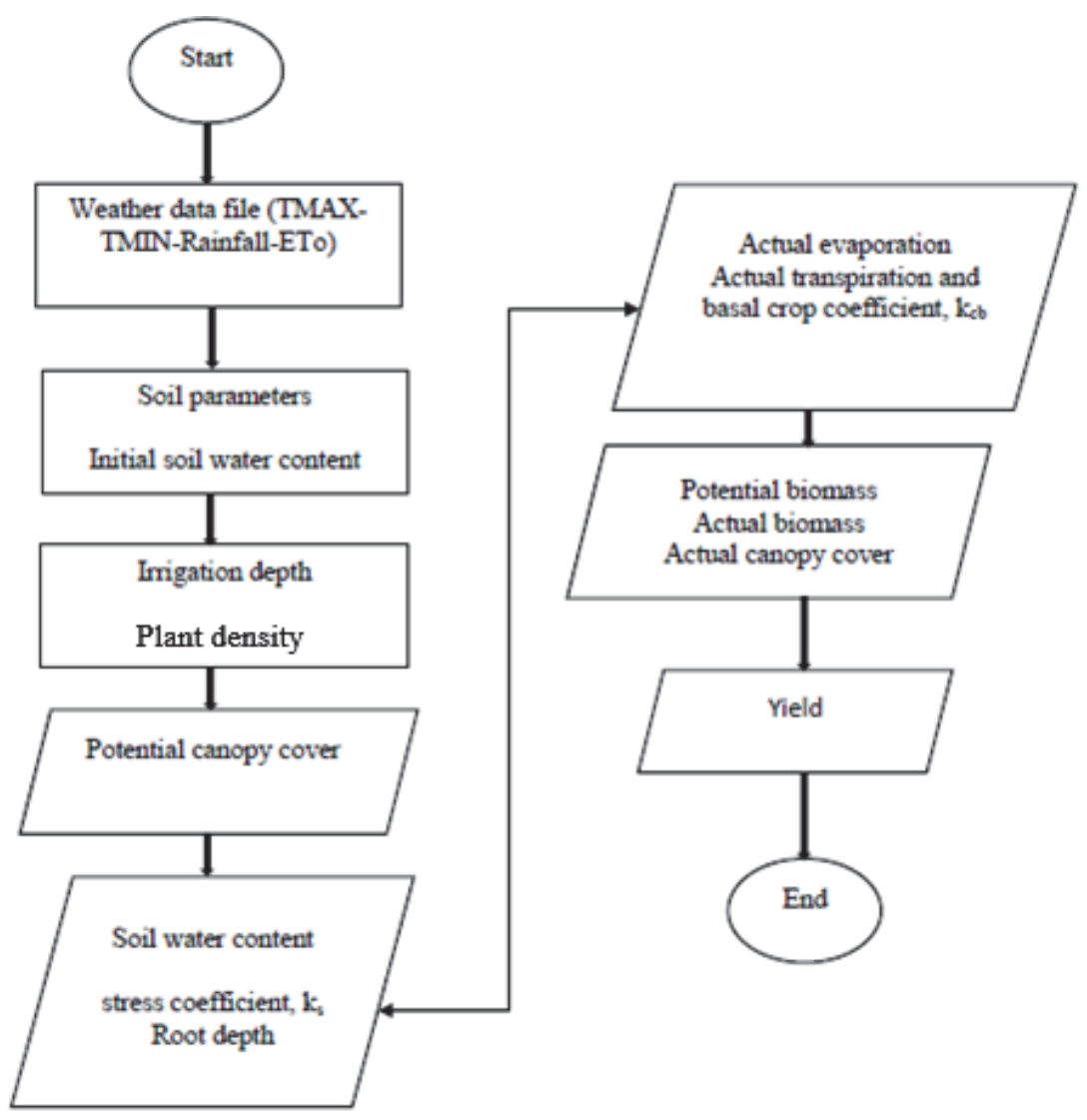

Figure 2. The flow chart of the Yield of Rbean Model

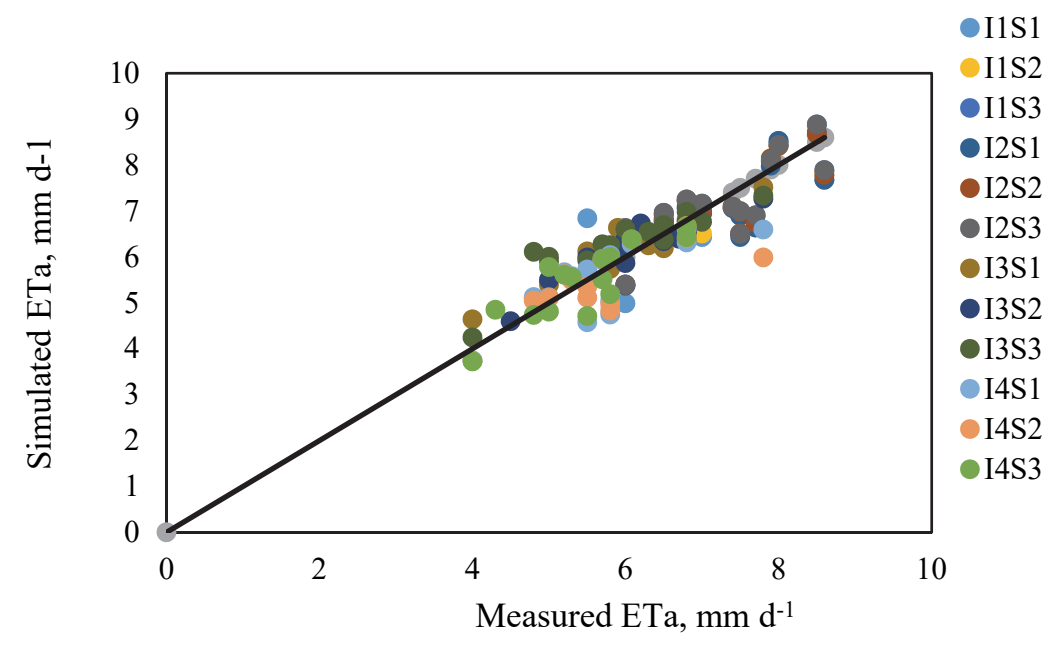

Figure 3. Relationship between the simulated and measured actual evapotranspiration (ETa) for different treatments during the growing season in 2013 (calibration data) 


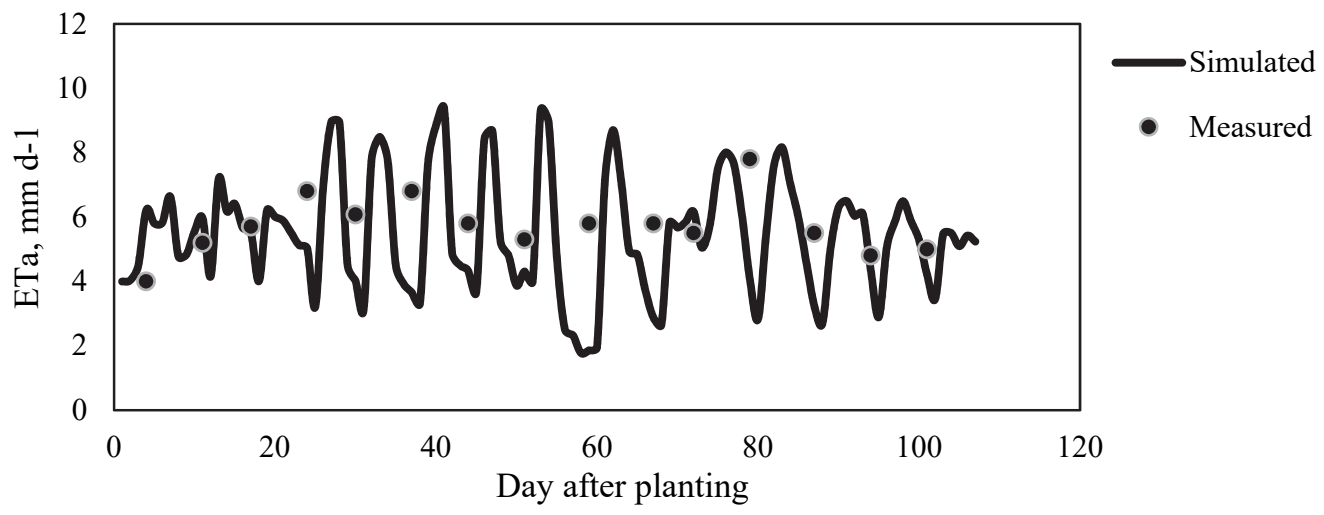

Figure 4. The amounts simulated and measured of the evapotranspiration (ETa) for the I4 irrigation level, during the growing season of 2013 (calibration data

Table 4. Relationship between the simulated and measured actual evapotranspiration (ETa) for different treatments during the growing season in 2013 (calibration data)

\begin{tabular}{cccccccc}
\hline Irrigation regim & $\begin{array}{c}\text { Within row } \\
\text { spacing }(\mathrm{cm})\end{array}$ & $\begin{array}{c}\text { Planting } \\
\text { density } \\
\text { plant } / \mathrm{m}^{2}\end{array}$ & Equation & $\mathrm{R}^{2}$ & $\mathrm{P}_{\text {value }}$ & $\mathrm{d}$ & NRMSE \\
\hline 1.2 ETo & 5 & 66 & Etas $=0.98$ ETam & 0.46 & $3.01 \times 10^{-6}$ & 0.99 & 0.09 \\
\hline $1.2 \mathrm{ETo}$ & 10 & 33 & Etas $=0.98$ ETam & 0.65 & $1.13 \times 10^{-7}$ & 0.99 & 0.07 \\
\hline $1.2 \mathrm{ETo}$ & 15 & 22 & Etas $=0.95 \mathrm{ETam}$ & 0.61 & $2.7 \times 10^{-7}$ & 0.99 & 0.07 \\
\hline $1.0 \mathrm{ETo}$ & 5 & 66 & Etas $=0.97 \mathrm{ETam}$ & 0.56 & $5.30 \times 10^{-7}$ & 0.99 & 0.08 \\
\hline $1.0 \mathrm{ETo}$ & 10 & 33 & Etas $=0.95 \mathrm{ETam}$ & 0.59 & $1.93 \times 10^{-16}$ & 0.99 & 0.07 \\
\hline $1.0 \mathrm{ETo}$ & 15 & 22 & Etas $=0.96 \mathrm{ETam}$ & 0.61 & $2.8 \times 10^{-7}$ & 0.99 & 0.07 \\
\hline $0.8 \mathrm{ETo}$ & 5 & 66 & Etas $=1.05 \mathrm{ETam}$ & 0.6 & $2.7 \times 10^{-7}$ & 0.99 & 0.06 \\
\hline $0.8 \mathrm{ETo}$ & 10 & 33 & Etas $=1.03 \mathrm{ETam}$ & 0.68 & $1.5 \times 10^{-10}$ & 0.99 & 0.06 \\
\hline $0.8 \mathrm{ETo}$ & 15 & 22 & Etas $=1.05 \mathrm{ETam}$ & 0.45 & $1.17 \times 10^{-8}$ & 0.99 & 0.07 \\
\hline $0.6 \mathrm{ETo}$ & 5 & 66 & Etas $=0.96 \mathrm{ETam}$ & 0.54 & $4.6 \times 10^{-6}$ & 0.99 & 0.10 \\
\hline $0.6 \mathrm{ETo}$ & 10 & 33 & Etas $=0.95 \mathrm{ETam}$ & 0.4 & $2.97 \times 10^{-5}$ & 0.99 & 0.11 \\
\hline $0.6 \mathrm{ETo}$ & 15 & 22 & Etas $=0.95 \mathrm{ETam}$ & 0.41 & $9.94 \times 10^{-6}$ & 0.99 & 0.09 \\
\hline
\end{tabular}

\subsubsection{Biomass}

Calibration of biomass (B) for some treatments as samples which were obtained from the first year is shown in Figure.5. Simulated and measured values of biomass for the first year exhibit correlations and relationships, the (calibrated stage) for different treatments during the growing season in 2013 are shown in Figure.6. For this year of the experiment, the NRMSE was observed to be lower than $10 \%$ for the different treatments of red bean (Table 5). Linear relationships between the measured and simulated biomass inherently included slopes and intercepts that were analyzed statistically. The intercept was insignificant to be considered effective for the biomass relationship; therefore, passing the origin of coordinates was achieved by the regression equation. Biomass could be estimated high accurately and the values of NRMSE and d showed this through the calibrated Rbean model (Table 5). The accumulation trend for plant dry matter (biomass) showed that the maximum dry matter is achieved in the irrigation treatment of $100 \% \mathrm{ET}_{\mathrm{o}}$. The minimum dry matter, however, occurs at $60 \%$ $\mathrm{ET}_{\mathrm{o}}$ irrigation treatment (Figure. 5). The accumulation trend for dry matter can be divided into two steps. The first step is at the time when plants receive 730 Growing Degree Days (GDD). The second step involves an extraordinary accumulation of dry matter which reaches a maximum trend corresponding to about 1700 GDD. Thereafter, the rate of dry matter accumulation declined as the plant moved toward the end of the growing season. It is indicated that the rate of dry matter accumulation increased as a result of the increase in irrigation water. Reasons for the slow trend of increase in biomass at the beginning of the growing season are explained by 
the small size of leaf area because the seedling is too small to perform effective exploitations of environmental resources, especially light. Consequently, it is presumed that water stress reduced the leaf area, thus the hampered vegetative growth did not allow for plants to receive light effectively. Therefore, photosynthesis was suppressed and the yield was affected, even though the density of plant cultivation was higher in comparison with the full irrigation treatment. This model acknowledges the mid-season increase in crop susceptibility which has also been observed in previous research. Firstly, when $\mathrm{K}_{\mathrm{cb}}$ is high (in the mid-season), water stress will have a larger effect on biomass and yield than early or late season stress. Also, $K_{s}$ is dependent on $T_{p}$, so that a higher evaporative demand (often in the mid-season) results in a greater reduction in $\mathrm{K}_{\mathrm{s}}$ for a given soil water level. Results of the model simulation for the red bean plant biomass at harvest are shown in Table 6 . The Rbean model has served as an acceptable estimation for biomass for most irrigation and density conditions. According to the results, it was realized that the simulated biomass in all treatments (for calibration data) corresponds quite well with the actual biomass (NRMSE $=2 \%$ ) (Table 6) and the regression coefficient for calibration data had a good correlation $\left(\mathrm{R}^{2}=0.90\right)$ between the simulated biomass and the actual biomass (Figure.7).
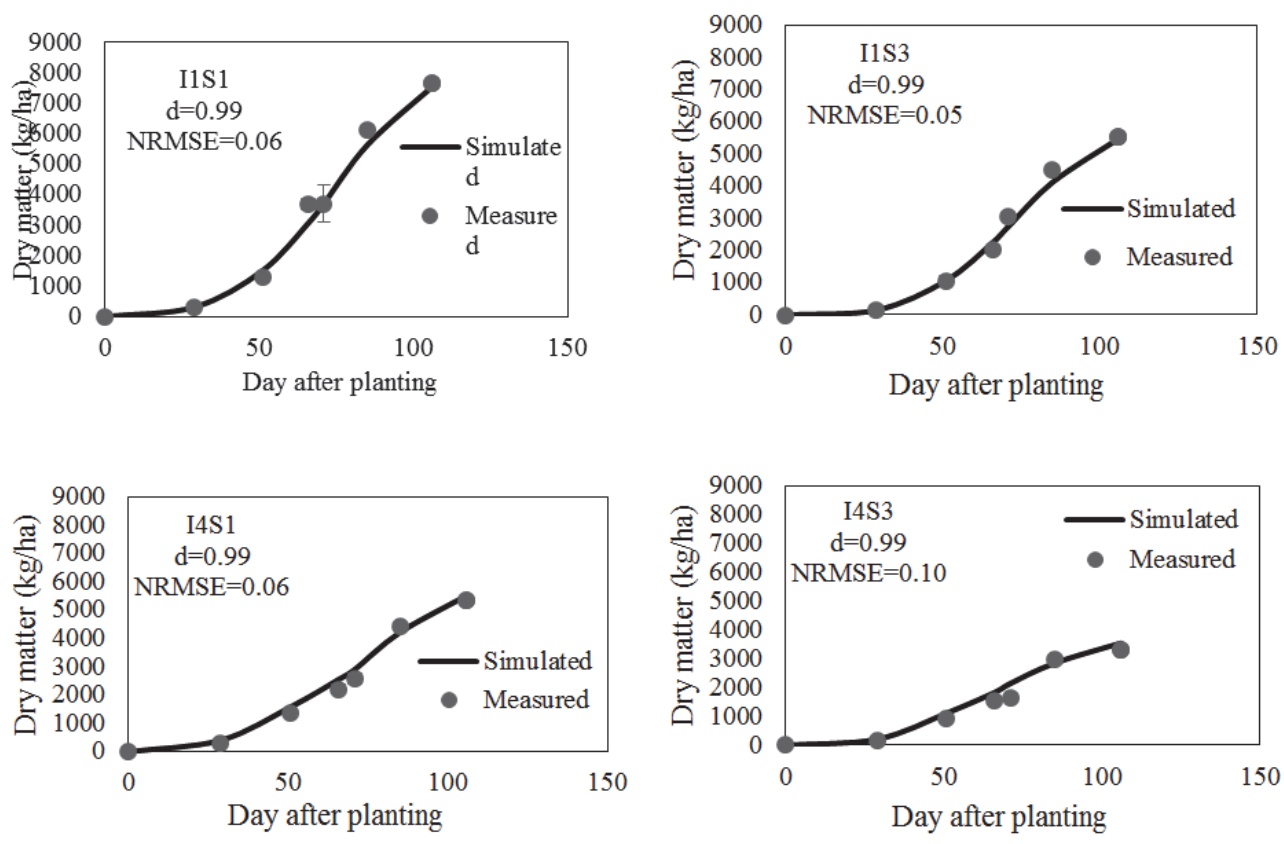

Figure 5. The amounts pertaining to the simulations (dashed lines) and measurements (solid lines) of biomass (B) and its development by the I1 and I4 irrigation levels, and by the S1 and S3 of plant spacing, during the growing season of 2013 (calibration data)

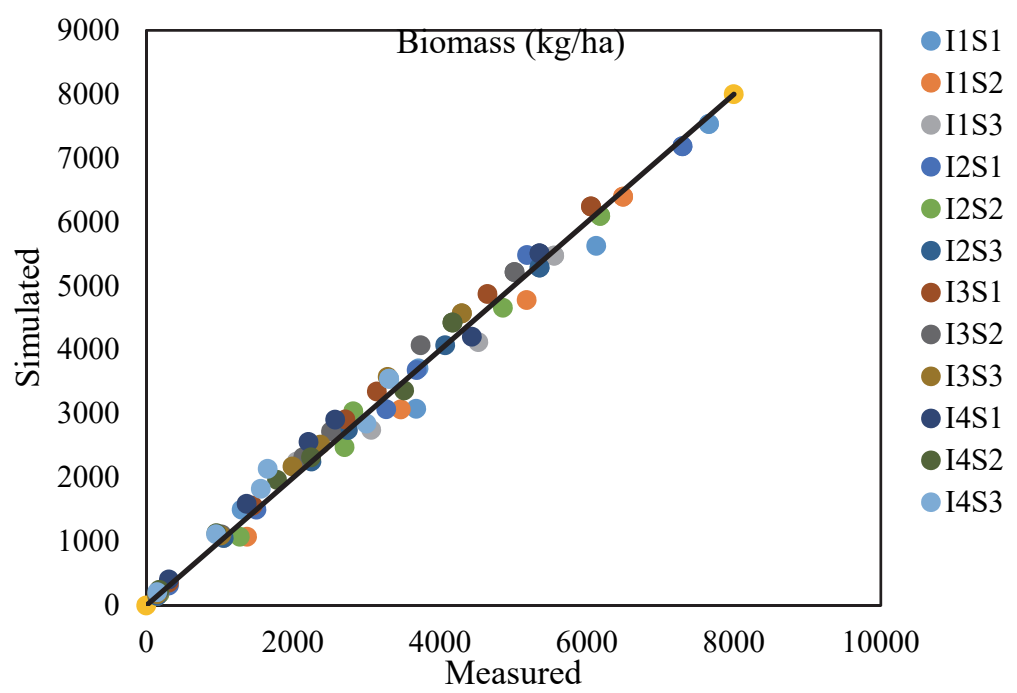

Figure 6. Relationship between the simulated and measured biomass (B) for all treatments during the growing season in 2013 (calibration data) 


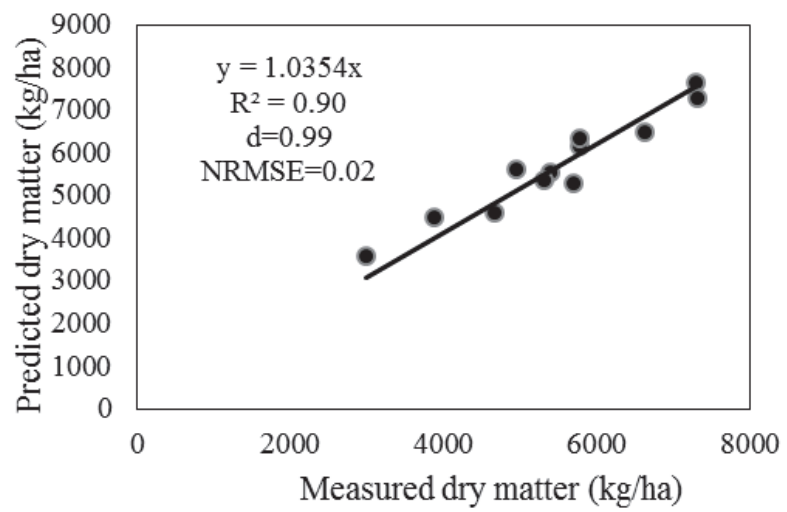

Figure 7. Comparison of the observed and simulated biomass at harvest in Rbean model $(\mathrm{kg} / \mathrm{ha})$ in 2013(calibration data)

Table 5. Relationship between the simulated and measured biomass (B) for different treatments during the growing season in 2013 (calibration data)

\begin{tabular}{|c|c|c|c|c|c|c|c|}
\hline $\begin{array}{l}\text { Irrigation } \\
\text { regim }\end{array}$ & $\begin{array}{l}\text { Within row spacing } \\
(\mathrm{cm})\end{array}$ & $\begin{array}{ll}\text { Plant } & \text { density } \\
\text { plant } / \mathrm{m}^{2} & \\
\end{array}$ & Equation & $\mathrm{R}^{2}$ & $\mathrm{P}_{\text {value }}$ & d & NRMSE \\
\hline $1.2 \mathrm{ETo}$ & 5 & 66 & $\mathrm{Bs}=0.96 \mathrm{Bm}$ & 0.99 & $2.41 \times 10^{-6}$ & 0.99 & 0.06 \\
\hline $1.2 \mathrm{ETo}$ & 10 & 33 & $\mathrm{Bs}=0.96 \mathrm{Bm}$ & 0.99 & $1.82 \times 10^{-6}$ & 0.99 & 0.05 \\
\hline $1.2 \mathrm{ETo}$ & 15 & 22 & $\mathrm{Bs}=0.96 \mathrm{Bm}$ & 0.99 & $1.79 \times 10^{-6}$ & 0.99 & 0.05 \\
\hline $1.0 \mathrm{ETo}$ & 5 & 66 & $\mathrm{Bs}=0.99 \mathrm{Bm}$ & 0.99 & $2.51 \times 10^{-7}$ & 0.99 & 0.03 \\
\hline 1.0 ETo & 10 & 33 & $\mathrm{Bs}=0.99 \mathrm{Bm}$ & 0.99 & $4.2 \times 10^{-7}$ & 0.99 & 0.03 \\
\hline 1.0 ETo & 15 & 22 & $\mathrm{Bs}=0.99 \mathrm{Bm}$ & 0.99 & $3.29 \times 10^{-11}$ & 0.99 & 0.01 \\
\hline 0.8 ETo & 5 & 66 & $\mathrm{Bs}=1.04 \mathrm{Bm}$ & 0.99 & $9.83 \times 10^{-10}$ & 0.99 & 0.04 \\
\hline $0.8 \mathrm{ETo}$ & 10 & 33 & $\mathrm{Bs}=1.06 \mathrm{Bm}$ & 0.99 & $1.72 \times 10^{-8}$ & 0.99 & 0.05 \\
\hline $0.8 \mathrm{ETo}$ & 15 & 22 & $\mathrm{Bs}=1.07 \mathrm{Bm}$ & 0.99 & $8.7 \times 10^{-10}$ & 0.99 & 0.06 \\
\hline $0.6 \mathrm{ETo}$ & 5 & 66 & $\mathrm{Bs}=1.03 \mathrm{Bm}$ & 0.99 & $2.63 \times 10^{-6}$ & 0.99 & 0.06 \\
\hline 0.6 ETo & 10 & 33 & $\mathrm{Bs}=1.04 \mathrm{Bm}$ & 0.99 & $1.76 \times 10^{-6}$ & 0.99 & 0.05 \\
\hline $0.6 \mathrm{ETo}$ & 15 & 22 & $\mathrm{Bs}=1.07 \mathrm{Bm}$ & 0.99 & $3.2 \times 10^{-5}$ & 0.99 & 0.10 \\
\hline
\end{tabular}

Table 6 . The measured and simulated biomass at harvest by using the Rbean model

\begin{tabular}{|c|c|c|c|c|c|c|}
\hline & & & \multicolumn{2}{|c|}{2013 (calibration) } & \multicolumn{2}{|c|}{2014 (validation) } \\
\hline Irrigation & Within row spacing & Plant & Measured & Simulated & Measured & Simulated \\
\hline regim & $(\mathrm{cm})$ & density & & & & \\
\hline & & Plant $/ \mathrm{m}^{2}$ & $\mathrm{~kg} / \mathrm{ha}$ & $\mathrm{kg} / \mathrm{ha}$ & $\mathrm{kg} / \mathrm{ha}$ & $\mathrm{kg} / \mathrm{ha}$ \\
\hline 1.2 ETo & 5 & 66 & 7290 & 7150 & 7870 & 7700 \\
\hline 1.2 ETo & 10 & 33 & 6630 & 6450 & 6591 & 6510 \\
\hline 1.2 ETo & 15 & 22 & 5400 & 5500 & 5960 & 5530 \\
\hline 1.0 ETo & 5 & 66 & 7320 & 7200 & 7935 & 7560 \\
\hline 1.0 ETo & 10 & 33 & 5770 & 6160 & 6720 & 6410 \\
\hline 1.0 ETo & 15 & 22 & 5320 & 5260 & 5750 & 5520 \\
\hline 0.8 ETo & 5 & 66 & 5780 & 5980 & 6748 & 7000 \\
\hline 0.8 ETo & 10 & 33 & 5700 & 4900 & 6150 & 6000 \\
\hline 0.8 ETo & 15 & 22 & 4957 & 4120 & 5270 & 4980 \\
\hline 0.6 ETo & 5 & 66 & 4950 & 5612 & 5690 & 6081 \\
\hline 0.6 ETo & 10 & 33 & 3880 & 4493 & 4420 & 5079 \\
\hline 0.6 ETo & 15 & 22 & 2980 & 3580 & 3302 & 4370 \\
\hline NRMSE (\%) & & & 2 & & 8 & \\
\hline
\end{tabular}




\subsubsection{Seed Yield}

Table 8 shows results of the model simulation for seed yield which are relatively similar to results of the simulated biomass obtained for each treatment, and a good correlation was found between the simulated and the measured seed yield (Table 7). It can be observed that the simulated yield in all treatments (for calibration data) is in good correlation with the actual yield (NRMSE $=7 \%$ ) (Table 7) and that the simulated yield and the measured yield correlate well with each other $\left(\mathrm{R}^{2}=0.95\right)$ by considering the regression coefficient for calibration data (Figure.8). Alizadeh et al. (2010) reported that the performance of the AquaCrop model is higher where irrigation water is applied optimally than where low amounts of water are irrigated.

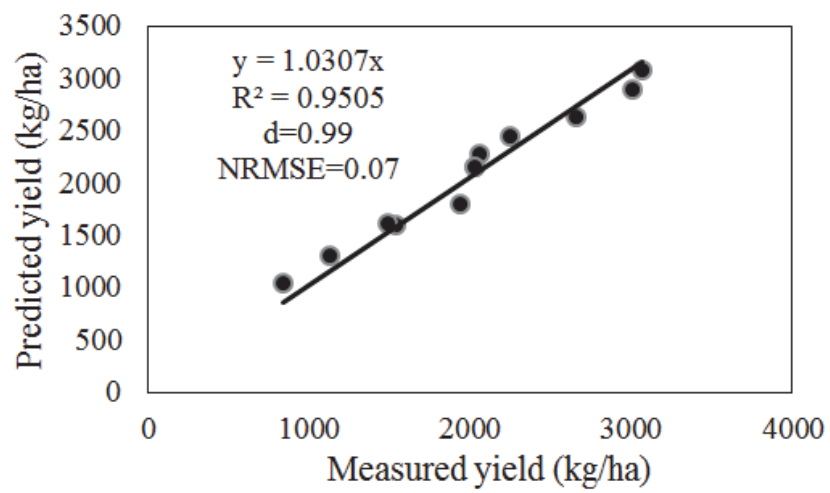

Figure 8. Comparison of observed and simulated yield in Rbean model (kg/ha) in 2013 (calibration data)

Table 7. The measured and simulated seed yield by using the Rbean model

\begin{tabular}{|c|c|c|c|c|c|c|c|}
\hline & $\begin{array}{l}\text { Within } \\
\text { spacing }\end{array}$ & row & $\begin{array}{l}\text { Planting } \\
\text { density }\end{array}$ & 2013 & (calibration) & 2014 & (validation) \\
\hline Irrigation regim & $(\mathrm{cm})$ & & plant $/ \mathrm{m}^{2}$ & $\begin{array}{l}\text { Measured } \\
\mathrm{kg} / \mathrm{ha}\end{array}$ & $\begin{array}{l}\text { Simulated } \\
\mathrm{kg} / \mathrm{ha}\end{array}$ & $\begin{array}{l}\text { Measured } \\
\mathrm{kg} / \mathrm{ha}\end{array}$ & $\begin{array}{l}\text { Simulated } \\
\mathrm{kg} / \mathrm{ha}\end{array}$ \\
\hline $1.2 \mathrm{ETo}$ & 5 & & 66 & 3062 & 3084 & 3305 & 3193 \\
\hline $1.2 \mathrm{ETo}$ & 10 & & 33 & 2652 & 2634 & 2636 & 2722 \\
\hline $1.2 \mathrm{ETo}$ & 15 & & 22 & 2052 & 2277 & 2265 & 2337 \\
\hline 1.0 ETo & 5 & & 66 & 3001 & 2895 & 3253 & 3170 \\
\hline 1.0 ETo & 10 & & 33 & 2250 & 2459 & 2621 & 2701 \\
\hline 1.0 ETo & 15 & & 22 & 2021 & 2158 & 2185 & 2317 \\
\hline 0.8 ETo & 5 & & 66 & 2023 & 2168 & 2362 & 2869 \\
\hline 0.8 ETo & 10 & & 33 & 1938 & 1808 & 2230 & 2472 \\
\hline 0.8 ETo & 15 & & 22 & 1537 & 1606 & 2001 & 2201 \\
\hline 0.6 ETo & 5 & & 66 & 1485 & 1614 & 1807 & 1917 \\
\hline 0.6 ETo & 10 & & 33 & 1125 & 1305 & 1451 & 1609 \\
\hline 0.6 ETo & 15 & & 22 & 834 & 1055 & 1150 & 1375 \\
\hline NRMSE(\%) & & & & 7 & & 9 & \\
\hline
\end{tabular}

\subsubsection{Simulation of Water Productivity (WP)}

Crop scientists express water productivity as the ratio of grain yield to total applied water on a seasonal basis (Sinclair et al. 1984). Water productivity is one of the most important indicators that determine what amount of irrigation can be considered as optimum. In 2013, the maximum yield was $3062 \mathrm{~kg} \mathrm{ha}^{-1}$, occurring at $120 \%$ of potential crop evapotranspiration, by the $5 \mathrm{~cm}$ spacing between the plants in each row. The maximum water productivity was $0.33 \mathrm{~kg} \mathrm{~m}^{-3}$ which occurred at $100 \%$ of potential evapotranspiration and by the $5 \mathrm{~cm}$ plant spacing. However, minimum yield and water use efficiency were $834 \mathrm{~kg} \mathrm{ha}^{-1}$ and $0.12 \mathrm{~kg} \mathrm{~m}^{-3}$, respectively, under the condition of $60 \%$ potential crop evapotranspiration and the spacing of $15 \mathrm{~cm}$ between the plants within a row. According to the results, it was realized that there is a good correlation between the simulated WP in all treatments (for calibration data) and the measured WP (NRMSE $=7 \%$ ) (Table 8). Furthermore, there was a considerable correlation between the simulated yield and the measured yield $\left(\mathrm{R}^{2}=0.88\right)$ because the regression 
coefficient for calibration data suggests accordingly (Figure.9). Hsiao et al. (2009) and Alizadeh (2010) conducted experiments on corn WP and showed that the AquaCrop model is not so well able to simulate water productivity (WP), especially when severe drought stresses are present.

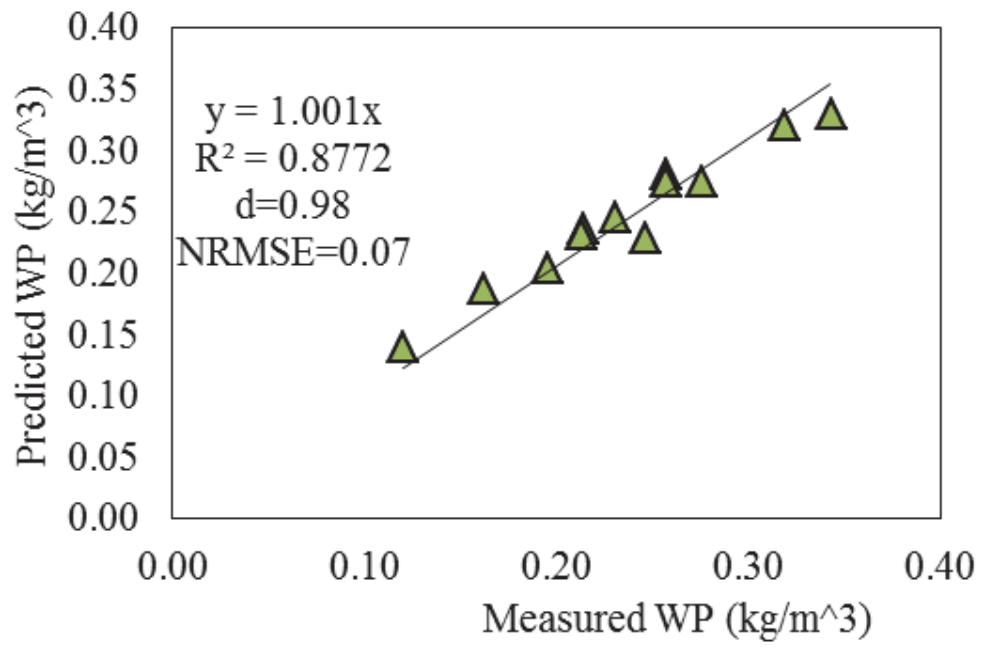

Figure 9. Comparison of observed and simulated WP in the Rbean model $\left(\mathrm{kg} / \mathrm{m}^{3}\right)$ in 2013 (calibration data)

Table 8 . The measured and simulated of WP by using the Rbean model.

\begin{tabular}{|c|c|c|c|c|c|c|}
\hline & & & 2013 & (calibration) & 2014 & (validation) \\
\hline Irrigation regim & Within row spacing & Planting density & Measured & Simulated & Measured & Simulated \\
\hline & $(\mathrm{cm})$ & plant/m2 & $\mathrm{kg} / \mathrm{m} 3$ & $\mathrm{~kg} / \mathrm{m} 3$ & $\mathrm{~kg} / \mathrm{m} 3$ & $\mathrm{~kg} / \mathrm{m} 3$ \\
\hline $1.2 \mathrm{ETs}$ & 5 & 66 & 0.32 & 0.32 & 0.30 & 0.29 \\
\hline $1.2 \mathrm{ETs}$ & 10 & 33 & 0.28 & 0.27 & 0.24 & 0.25 \\
\hline 1.2 ETs & 15 & 22 & 0.21 & 0.24 & 0.21 & 0.21 \\
\hline $1.0 \mathrm{ETs}$ & 5 & 66 & 0.33 & 0.33 & 0.34 & 0.33 \\
\hline $1.0 \mathrm{ETs}$ & 10 & 33 & 0.26 & 0.28 & 0.27 & 0.28 \\
\hline $1.0 \mathrm{ETs}$ & 15 & 22 & 0.23 & 0.25 & 0.23 & 0.24 \\
\hline $0.8 \mathrm{ETs}$ & 5 & 66 & 0.26 & 0.28 & 0.28 & 0.30 \\
\hline $0.8 \mathrm{ETs}$ & 10 & 33 & 0.25 & 0.23 & 0.27 & 0.29 \\
\hline $0.8 \mathrm{ETs}$ & 15 & 22 & 0.23 & 0.20 & 0.24 & 0.26 \\
\hline $0.6 \mathrm{ETs}$ & 5 & 66 & 0.21 & 0.23 & 0.25 & 0.27 \\
\hline $0.6 \mathrm{ETs}$ & 10 & 33 & 0.16 & 0.18 & 0.20 & 0.23 \\
\hline $0.6 \mathrm{ETs}$ & 15 & 22 & 0.12 & 0.14 & 0.17 & 0.19 \\
\hline NRMSE(\%) & & & 7 & & 7 & \\
\hline
\end{tabular}

\subsection{Model Validation}

\subsubsection{Evapotranspiration}

The presentation of relationships are presented between the simulated and measured values of seasonal actual evapotranspiration (ETa) for the second year, shown as the validation stage for different treatments during the growing season in 2014 (Figure.10). Linear relationship between the measured and simulated Eta inherently included slops and intercepts that were analyzed statistically. The intercept was insignificant to be considered effective for the ETa relationship; therefore passing the origion of coordinates was achieved by the regression equation. The values of NRMSE and d showed that the calibrated Rbean model could estimate ETa with high accuracy (Table 9). Calibration of actual evapotranspiration (ETa) for I4 irrigation level as sample in the second year, are shown in Figure.11. Because of the measured data was weekly mean and simulate data was daily, cause to different between measured and simulated data. 


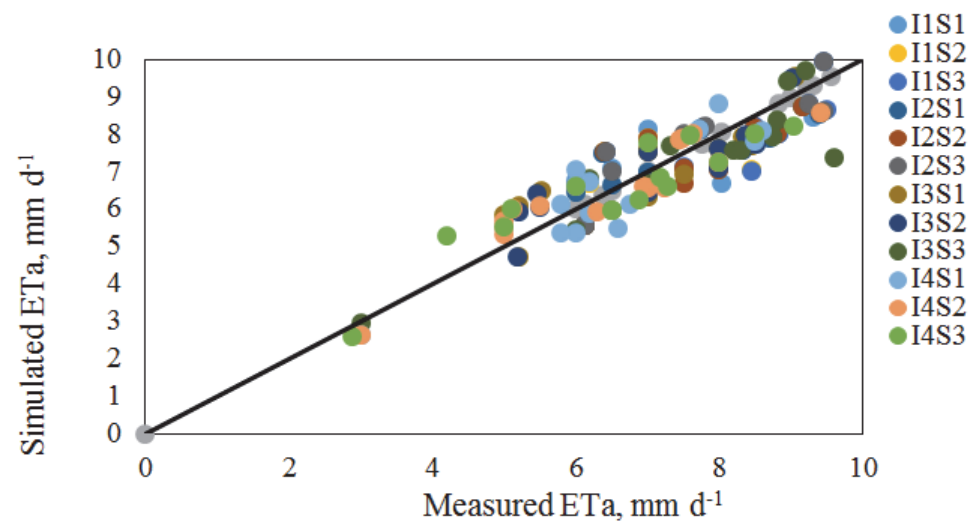

Figure 10. Relationship between the simulated and measured actual evapotranspiration (ETa) for different treatments during the growing season in 2014 (validation data)

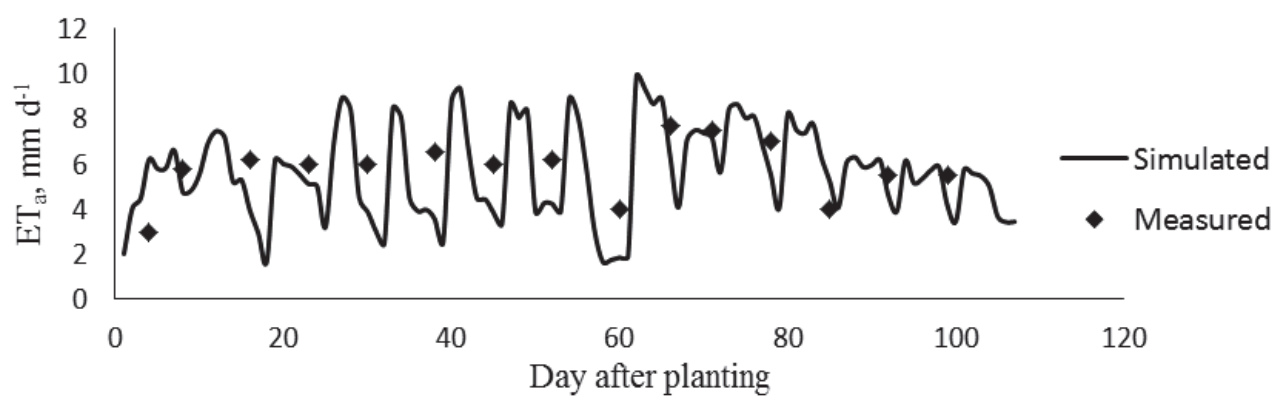

Figure 11. The amounts simulated (dashed lines) and measured (solid lines) of evapotranspiration (ETa) for I4 irrigation level, during the growing season of 2014 (validation data)

Table 9. Relationship between the simulated and measured actual evapotranspiration (ETa) for different treatments during the growing season in 2014 (validation data).

\begin{tabular}{cccccccc}
\hline & $\begin{array}{c}\text { Within row } \\
\text { spacing } \\
(\mathrm{cm})\end{array}$ & $\begin{array}{c}\text { Planting } \\
\text { density } \\
\text { plant/m }\end{array}$ & Equation & $\mathrm{R}^{2}$ & $\mathrm{P}_{\text {value }}$ & $\mathrm{d}$ & NRMSE \\
\hline rrigation regim & 5 & 66 & Etas=0.95ETam & 0.63 & $2.37 \times 10^{-6}$ & 0.96 & 0.09 \\
\hline 1.2 ETo & 10 & 33 & Etas=0.95ETam & 0.60 & $3.66 \times 10^{-7}$ & 0.99 & 0.09 \\
\hline 1.2 ETo & 15 & 22 & Etas=0.95ETam & 0.58 & $2.76 \times 10^{-7}$ & 0.99 & 0.09 \\
\hline 1.2 ETo & 5 & 66 & Etas=0.95ETam & 0.63 & $1.52 \times 10^{-6}$ & 0.99 & 0.10 \\
\hline 1.0 ETo & 10 & 33 & Etas=0.95ETam & 0.60 & $1.48 \times 10^{-7}$ & 0.99 & 0.09 \\
\hline 1.0 ETo & 15 & 22 & Etas=0.95ETam & 0.58 & $3.4 \times 10^{-7}$ & 0.99 & 0.08 \\
\hline 1.0 ETo & 5 & 66 & Etas=0.95ETam & 0.69 & $5.7 \times 10^{-7}$ & 0.99 & 0.10 \\
\hline 0.8 ETo & 10 & 33 & Etas=0.92ETam & 0.68 & $4.07 \times 10^{-7}$ & 0.99 & 0.09 \\
\hline 0.8 ETo & 15 & 22 & Etas=1.02ETam & 0.74 & $1.44 \times 10^{-7}$ & 0.99 & 0.10 \\
\hline 0.8 ETo & 5 & 66 & Etas=0.96ETam & 0.67 & $3.41 \times 10^{-6}$ & 0.99 & 0.11 \\
\hline 0.6 ETo & 10 & 33 & Etas=0.94ETam & 0.65 & $5.65 \times 10^{-8}$ & 0.99 & 0.09 \\
\hline 0.6 ETo & 15 & 22 & Etas=0.94ETam & 0.63 & $1.34 \times 10^{-7}$ & 0.99 & 0.10 \\
\hline 0.6 ETo & & & & & & &
\end{tabular}

\subsubsection{Biomass}

To validate the Rbean model, the measured field data of the second year of the experiment (in 2014) was used. For the second year, the relationships between the simulated and measured values of biomass are taken into notice when exploring the validation stage for the different treatments during the growing season in 2014 (Figure.12 and 13). For this year of the experiment, the NRMSE became lower than 9\% for the different treatments of red bean (Table 10). The slopes and intercepts of the linear relationships between the measured and 
simulated biomass were analyzed statistically. The intercept was not significant for biomass relationship; therefore, the regression equation was forced to pass the origin of coordinates. The values of NRMSE and d showed that the calibrated Rbean model could estimate biomass with high accuracy (Table 10). The accumulation trend for plant dry matter (biomass) showed that the maximum dry matter is achieved in $100 \%$ potential crop evapotranspiration irrigation. The minimum dry matter, however, occurred at the $60 \%$ potential evapotranspiration irrigation (Figure.12).

Model simulation of the red bean biomass resulted in measured data (Table 10). The Rbean model is capable of estimating biomass for most irrigation and density conditions. It is understood that the simulated biomass in all treatments (for validation data) corresponds quite well with the measured biomass (NRMSE $=8 \%$ ) (Table 10) and the regression coefficient for validation data had good correlation $\left(\mathrm{R}^{2}=0.83\right)$ between the simulated biomass and the measured biomass (Figure.14).
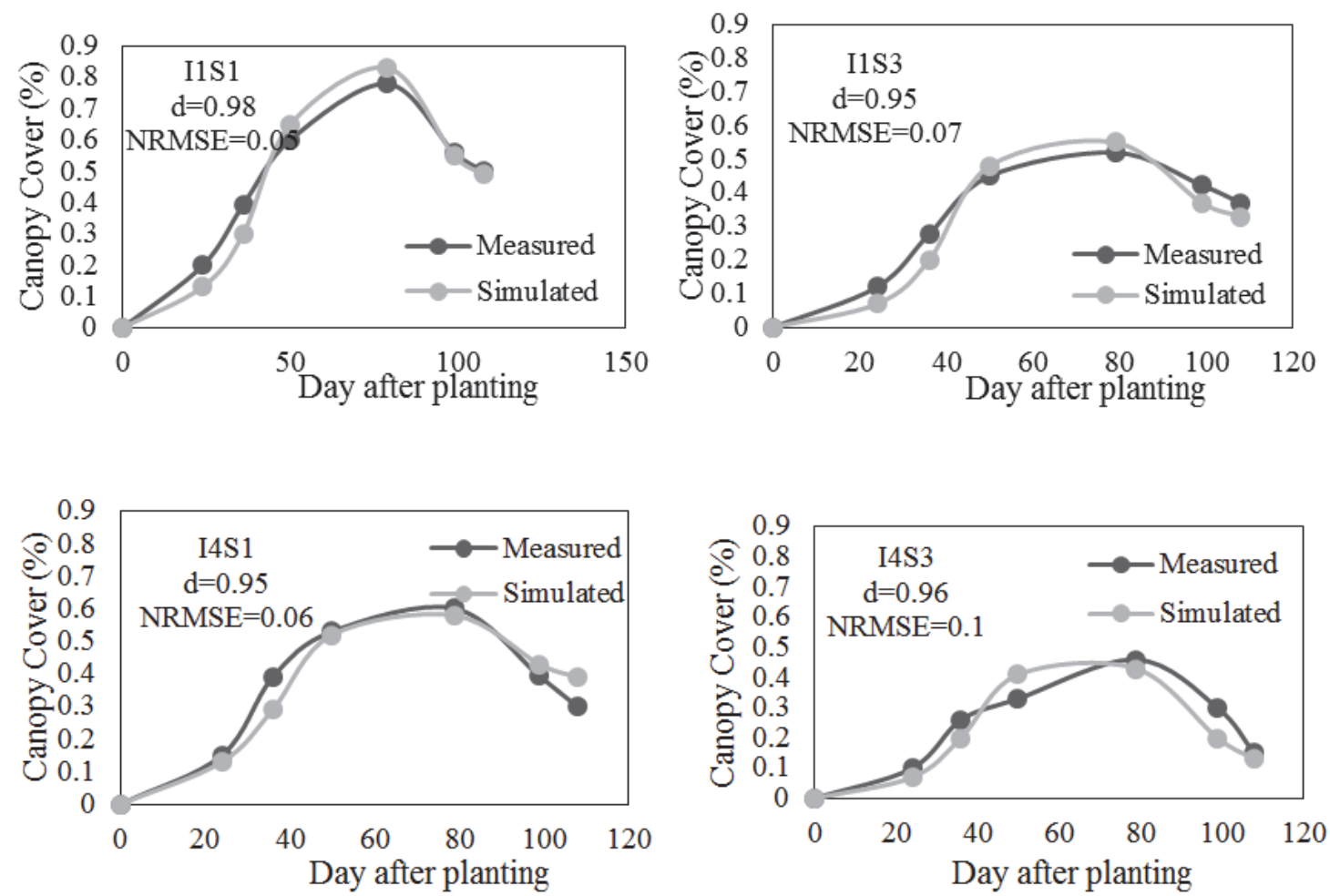

Figure 12. The amounts simulated (dashed lines) and measured (solid lines) of canopy cover development by the I1 and I4 irrigation levels, and the S1 and S3 of plant spacing, during the growing season of 2014 (validation data)

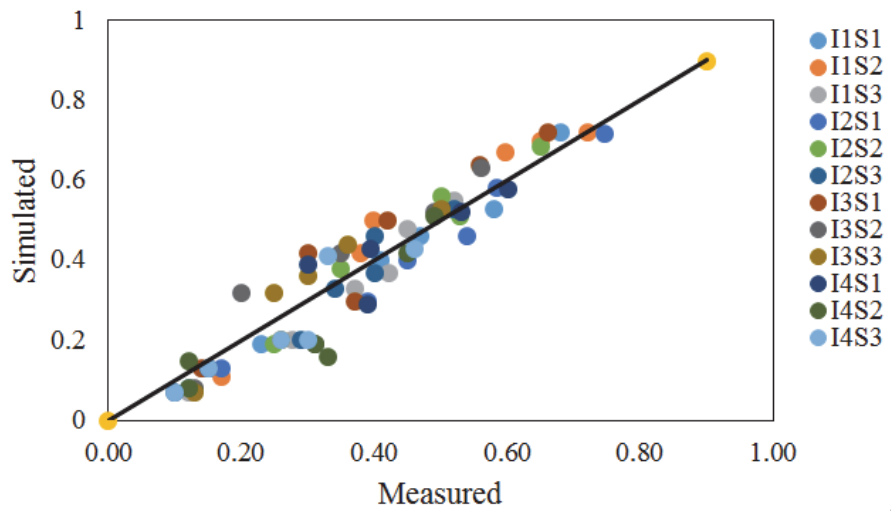

Figure 13. Relationship between the simulated and measured canopy cover (CC) for all treatments during the growing season in 2014 (validation data) 


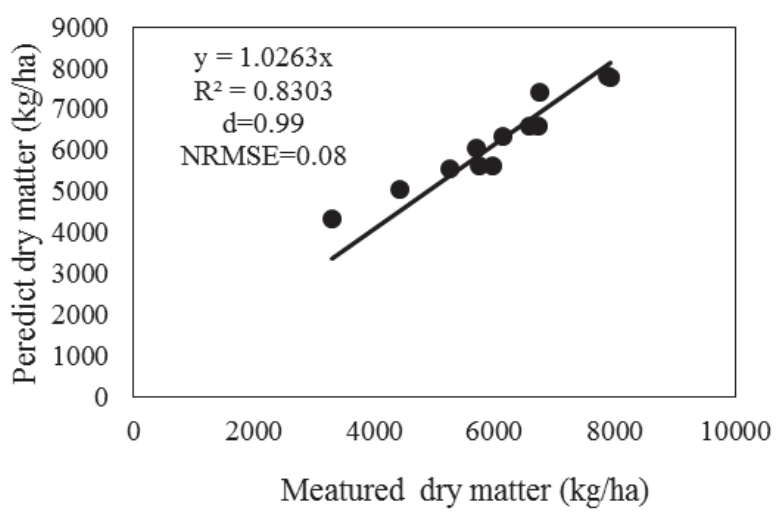

Figure 14. Comparison of observed and simulated biomass in Rbean model (kg/ha) in 2014(validation data)

Table 10. Relationship between the simulated and measured biomass (B) for each treatment during the growing season in 2014 (validation data)

\begin{tabular}{ccccccc}
\hline Irrigation regime & $\begin{array}{c}\text { Within row spacing } \\
(\mathrm{cm})\end{array}$ & Plant density (plant $\left./ \mathrm{m}^{2}\right)$ & Equation & $\mathrm{R}^{2}$ & $\mathrm{P}_{\text {value }}$ & NRMSE \\
\hline $1.2 \mathrm{ETo}$ & 5 & 66 & $\mathrm{Bs}=0.98 \mathrm{Bm}$ & 0.99 & $8.1 \times 10^{-8}$ & 0.03 \\
\hline $1.2 \mathrm{ETo}$ & 10 & 33 & $\mathrm{Bs}=0.98 \mathrm{Bm}$ & 0.99 & $6.9 \times 10^{-8}$ & 0.03 \\
\hline $1.2 \mathrm{ETo}$ & 15 & 22 & $\mathrm{Bs}=0.99 \mathrm{Bm}$ & 0.99 & $3.0 \times 10^{-8}$ & 0.02 \\
\hline $1.0 \mathrm{ETo}$ & 5 & 66 & $\mathrm{Bs}=0.98 \mathrm{Bm}$ & 0.99 & $3.7 \times 10^{-7}$ & 0.04 \\
\hline $1.0 \mathrm{ETo}$ & 10 & 33 & $\mathrm{Bs}=0.97 \mathrm{Bm}$ & 0.99 & $1.5 \times 10^{-7}$ & 0.04 \\
\hline $1.0 \mathrm{ETo}$ & 15 & 22 & $\mathrm{Bs}=1.01 \mathrm{Bm}$ & 0.99 & $5.2 \times 10^{-7}$ & 0.04 \\
\hline $0.8 \mathrm{ETo}$ & 5 & 66 & $\mathrm{Bs}=1.04 \mathrm{Bm}$ & 0.99 & $4.9 \times 10^{-3}$ & 0.05 \\
\hline $0.8 \mathrm{ETo}$ & 10 & 33 & $\mathrm{Bs}=1.06 \mathrm{Bm}$ & 0.99 & $9.9 \times 10^{-8}$ & 0.07 \\
\hline $0.8 \mathrm{ETo}$ & 15 & 22 & $\mathrm{Bs}=1.08 \mathrm{Bm}$ & 0.99 & $3.5 \times 10^{-8}$ & 0.09 \\
\hline $0.6 \mathrm{ETo}$ & 5 & 66 & $\mathrm{Bs}=1.07 \mathrm{Bm}$ & 0.99 & $3.3 \times 10^{-7}$ & 0.07 \\
\hline $0.6 \mathrm{ETo}$ & 10 & 33 & $\mathrm{Bs}=1.07 \mathrm{Bm}$ & 0.99 & $1.4 \times 10^{-7}$ & 0.08 \\
\hline $0.6 \mathrm{ETo}$ & 15 & 22 & $\mathrm{Bs}=1.05 \mathrm{Bm}$ & 0.99 & $5.4 \times 10^{-7}$ & 0.06 \\
\hline
\end{tabular}

\subsubsection{Seed Yield}

Table 7 shows the results of the model simulation for seed yield. This is partly similar to the results of the simulated biomass. The simulated seed yield in each treatment had good correlation with the measured seed yield (Table 7). Recognitions were made on the yield simulation in all treatments (for validation data) and corresponded quite well with the measured yield (NRMSE=9\%) (Table 7). Validation data regarding the regression coefficient had good correlation $\left(\mathrm{R}^{2}=0.90\right)$ among the simulated yield and the measured yield (Figure.15).

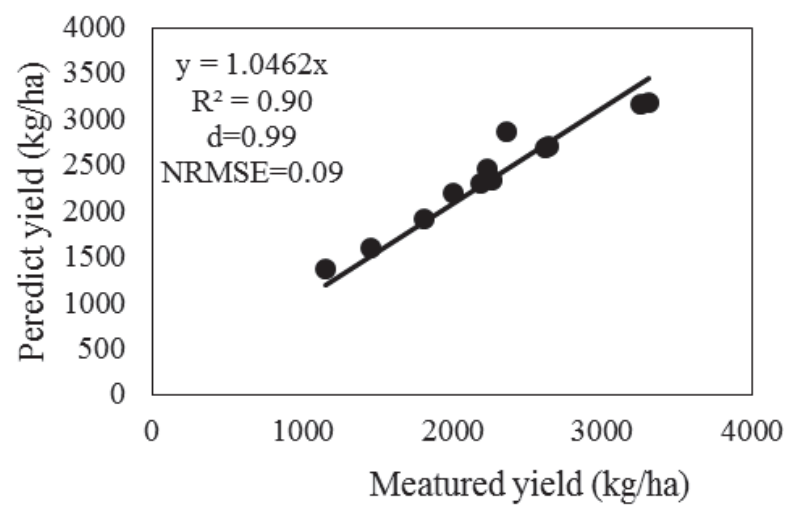

Figure 15. Comparison of observed and simulated yield in Rbean model (kg/ha) in 2014 (validation data) 


\subsubsection{Water Productivity}

In 2014, the maximum seed yield and water productivity were $3305 \mathrm{~kg} \mathrm{ha}^{-1}$ and $0.33 \mathrm{~kg} \mathrm{~m}^{-3}$, respectively, in the case of $100 \%$ potential crop evapotranspiration and by having the $5 \mathrm{~cm}$ spacing between the plants within each row. Minimum yield and water productivity were $1150.0 \mathrm{~kg} \mathrm{ha}^{-1}$ and $0.17 \mathrm{~kg} \mathrm{~m}^{-3}$, respectively, under the condition of $60 \%$ potential crop evapotranspiration and by having the $15 \mathrm{~cm}$ spacing between the plants within each row. Simulated WP in all treatments (for validation data) corresponded fairly with the measured WP $(\mathrm{NRMSE}=7 \%)($ Table 8$)$. The simulated seed yield and the measured yield had good correlation $\left(\mathrm{R}^{2}=0.98\right)$ with respect to the regression coefficient for validation data (Figure.16).

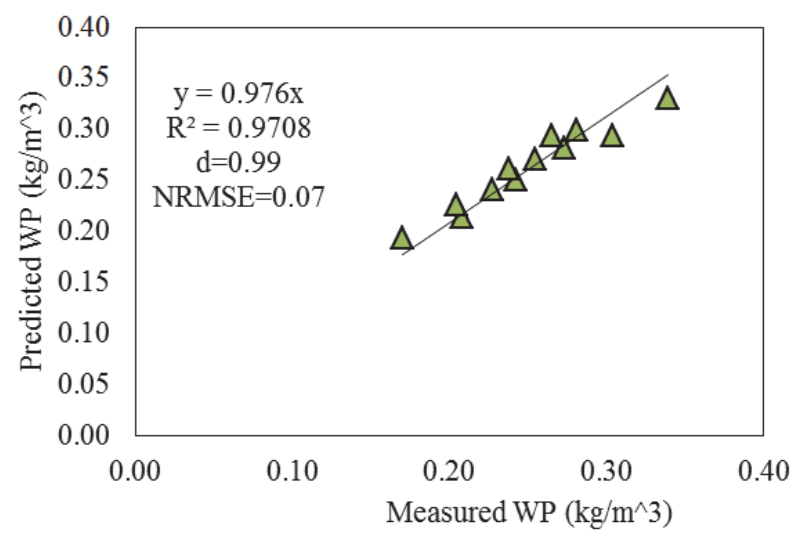

Figure 16. Comparison between the observed and simulated WP in Rbean model $\left(\mathrm{kg} / \mathrm{m}^{3}\right)$ in 2014 (validation data)

\section{Discussion}

Model outputs matched well with the actual measurements. Results illustrate that the model has the ability to reflect the plant density effect on canopy cover, biomass, the yield, and water productivity. The Rbean model was developed to estimate red bean biomass based on a normalized transpiration ratio. Model results are fairly similar to field data regarding deficit irrigation on the red bean in this research, arguing that the model explained yield loss by water stress. Considering the results of this research, we can claim that the red bean is substantially susceptible to drought stress in general. Results show that by increasing the density of plant cultivation, enough leaf area is still present to receive sunlight. This, in fact, optimizes energy consumption by the plant population as a whole, and ultimately increases the yield and its components per unit of land area. The simplicity of this model has made it practically easy to use because of the minimum input of data it requires, which are readily available or can easily be collected for the model to operate. It provides a reference for decision-makers using limited experimental facilities, and it can be used in plant growth prediction, manufacture management, and the like. Finally, we suggest that it is feasible to evaluate the performances of the Rbean model in conditions of (i) different climates that are colder or warmer than our region in the present study and (ii) sowing the red bean on different dates from April to May.

\section{Acknowledgment}

Partial funding for this research (Grant \#94GCU2M1891, Shiraz University Research Council), is greatly acknowledged.

\section{References}

Abassi, A., \& Maleki, A. (2015). Yield and yield components of red bean cultivars in different planting pattern as a second cropping in Kermanshah climate, Iran. Journal of Biodiversity and Environmental Sciences (JBES), 2220-663. https://doi.org/10.1.1.736.3378\&rep=rep1\&type=pdf

Alizade, H. A., Nazari, B., Parsinejad, M., Ramazani Etedali, H., \& Janbaz, H. R. (2010). Evaluation of AquaCrop model in low irrigation management of wheat in Karaj region. Iranian Journal of Irrigation and Drainage, 2(4), 273-283. (In Persian with English Summery).

Allen, R. G., Walter, I. A., Elliot, R. L., \& Howell, A. (2005). ASCE standardized reference evapotranspiration equation. Reston, Va.: ASCE. https://doi.org/10.1061/40499(2000)126

Allen, R. G., Wright, J. L., Pruitt, W. O., Pereira, L. S., \& Jensen. M. E. (2007). Design and operation of farm 
irrigation systems, 209-288. G. J. Hoffman, R. G. Evans, M. E. Jensen, D. L. Martin, \& R. L. Elliott, eds. St. Joseph, Mich.: ASABE. International Standard Book Number (ISBN) 1-892769-64-6. https://doi.org/10.13031/2013.23705

Allen, R., Pereira, L., Raes, D., \& Smith, M., (1998). Crop Evapotranspiration e Guidelines for Computing Crop Water Requirements. FAO Irrigation and Drainage Paper No. 56. Rome, Italy. Retrieved from http://www.academia.edu/download/40878584/Allen_FAO1998.pdf

Azami, M., MonavvariFard, F., Jeyhoni, S., Eydi, S., Reyhani, H., \& Ghadimi, S. A. (2013). The Analysis of Effective Factors on Non-Accepting of Organic Agriculture Products from the Viewpoint of Agricultural Experts (Case Study: Alborz province). Int. j. Advanced. Biological \& Biomedical Research Journal (IJABBR), 1(3), 260-272. Retrieved from http://www.ijabbr.com

Board, J. E., \& Harville, B. G. (1996). Growth dynamics during the vegetative period effects on yields of narrow $\begin{array}{lllll}\text { row. } \quad \text { late-planted } & \text { Soybean }\end{array}$ https://doi.org/10.2134/agronj1996.00021962008800040012x

Boote, K. J., Jones, J. W., \& Pickering, N. B. (1996). Potential uses and limitations of crop models. Agronomy Journal, 88, 704-716. https://doi.org/10.2134/agronj1996.00021962008800050005x

Bradford, K. J., \& Hsiao, T. C. (1982). Physiological responses to moderate water stress. In: Lange., O.L. Nobel, P.S. Osmond, C.B.O., Ziegler, H. (Eds.), Physiological Plant Ecology II. Water Relations and Carbon Assimilation, Encyclopedia of Plant Physiology, New Series, vol. 12B. Springer-Verlag. NY, pp. 263-324. https://doi.org/10.1007/978-3-642-68150-9_10

De Oliveira., E. C. H., Da Costa, J. M. N., de Paula Júnior, T. J., Marques Ferreira, W. P., Justino, F. B., \& De Oliveira Neves, L. (2012). The performance of the CROPGRO model for bean (Phaseolus vulgaris L.) yield simulation. Acta Scientiarum. Agronomy 239-246. https://doi.org/10.4025/actasciagron.v34i3.13424

Denmead, O. T., \& Shaw, R. H. (1962). Availability of soil water to plants as affected by soil moisture content and meteorological conditions. Agronomy Journal, 54(5), 54(5), 385-390. https://doi.org/10.2134/agronj1962.00021962005400050005x

Emam, Y., \& Seghatoleslami, M. J. (2005). Crop Yield: biomass to reproductive organs to a large extent Physiology and Processes. First edition. Shiraz determines sink establishment and economic yield under University Inc., Shiraz. pp, 593. (In Persian).

Emam, Y., Shekoofa, A., Salehi, F., \& Jalali, A. H. (2010). Water Stress Effects on Two Common Bean Cultivars with Contrasting Growth Habits. American European Journal Agriculture and Environment. Science, 9(5), 495-499. Retrieved from http://www.idosi.org/aejaes/jaes9(5)/6.pdf

FAO. FAOSTAT, Food and Agricultural Organization of the United Nations. (2008). Retrieved from http://faostat.fao.org/

Garcia-Vila, M., Fereres, E., Mateos, L., Orgaz, F., \& Steduto. P. (2009). Déficit irrigation optimization of cotton with AquaCrop. Agronomy Journal, 101, 477-487. https://doi.org/10.2134/agronj2008.0179s

Heeren, D. M., Trooien, T. P., Werner, H. D., \& Klocke, N. L. (2011). Developing of deficit irrigation strategies for corn using a yield ratio model. American Society Agriculture and Biology Engineers Journal, 27(4), 605-614.

Hoogenboom, G., Jones, J. W., Wilkens, P. W., Hunt, L. A., Ports, C., H. Batchelor, W. D., .. Tsuji, G. Y. (2003). Decision support system for agrotechnology transfer: version 4.0. Honolulu: University of Hawaii. Retrieved from http://link.springer.com/chapter/10.1007/978-94-011-2842-1_28

Hsiao, T. C., Heng, L. K., Steduto, P., Raes, D., \& Fereres E. (2009). AquaCrop-Model parameterization and testing for maize. Agronomy Journal, 101, 448-459. https://doi.org/10.2134/agronj2008.0218s

Jamieson, P.D., Porter, J.R., \& Wilson, D.R. (1991). A test of the computer simulation model ARCWHEAT1on wheat crops grown in New Zealand. Field Crops Research Journal, 27, 337-350. https://doi.org/10.1016/0378-4290(91)90040-3

Keeling, C. D., Bacastow, R. B., Bainbridge, A. E, Ekdahl Jr, C. A., Guenther, P. R., \& Waterman, L. S. (1976). Atmospheric carbon dioxide variations at Mauna Loa Observatory. Hawaii. Tellus, 28(6), 538-555. https://doi.org/10.1111/j.2153-3490.1976.tb00701.x

Kochaki, E., \& Banaianaval, M., (1994). Crop plants yield physiology. JDM press, Mashhad, Iran. 380 p. (In 
Persian).

Machado Neto, N. B., \& Durães, M. A. B. (2006). Overall, drought stress has considerable impact Physiological and biochemical response of common on common bean growth and seed yield although bean varieties treated with salicylic acid under water the ranges of reductions are highly variable due to stress. Crop Breeding applied Biotechnology Journal, 6, 269-277. http://www.idosi.org/aejaes/jaes9(5)/6.pdf

Mohamadzadeh, M., Siadat, S. A., Norof, M. S., \& Naseri, R. (2011). The effects of plaanting date and row spacing on yield, yield components and associated traits in winter safflower under rain fed conditions. American-Eurasian Journal Agriculture \& Environmental Science, 10(2), 200-206. Retrieved from http://www.idosi.org/aejaes/jaes10(2)/12.pdf

Nazaralizadeh, K., Naseri, R., Mirzeai, A., \& Soleymanifard, A. (2012). Effects of planting pattern on yield, its components, oil contain and some important agronomic traits of Safflower (Carthamustinctorius L.) in dry land conditions. International Journal of Agriculture Crop Science, 4(2), 86-91. Retrieved from http://ijagcs.com/wp-content/uploads/2012/04/86-91.pdf

Ramos, M. L. G., Gordon, A. J., Minchin, F. R., Sprent, J. I., \& Parson, P. (1999). Effect of water stress on nodule physiology and biochemistry of a drought tolerant cultivar of common bean (Phaseolus vulgaris L.). Annals Botany Journal, 83, 57-63. https://doi.org/10.1006/anbo.1998.0792

Rase, D., Steduto, P., Hsiao, T. C., \& Fereres, E. (2009). AquaCrop-the FAO crop model to simulate yield response to water: II. Main algorithms and software description. Agronomy Journal, 101, 438-447. https://doi.org/10.2134/agronj2008.0140s

Razzaghi, F., \& Sepaskhah, A. (2012). Calibration and validation of four common ETo estimation equations by lysimeter data in a semi-arid environment. Arch. Agronomy Soil Science, 58, $303-319$. https://doi.org/10.1080/03650340.2010.518957.

Sinclair, T.R., Tanner, C.B., \& Bennnet, J.M. (1984). Water use efficiency in crop production. Bioscience, 34, 36-40. https://doi.org/10.2307/1309424

Singh, S. P., Terán, H., Munoz, C. G., \& Takegami, J. C. (1999). Two cycles of recurrent selection for seed yield in common bean. Crop Science Journal, 391-397. https://doi.org/10.2135/cropsci1999.0011183X0039000200015x

Steduto, P., \& Hsiao, T. C., Fereres, E. (2007). On the conservative behavior of biomass water productivity. Irrigation Science Journal, 25(3), 189-207. https://doi.org/10.1007/s00271-007-0064-1

Steduto, P., Fereres, E., Hsiao, T. C., \& Raes, D. (2006). Yield Response to Water, The FAO revision framework and the crop water productivity model Aqua Crop. In Proc Of International Symposium on Water and Land Management for Sustainable Irrigated Agriculture, Turkey: Irrigation and Agricultural Structures Department, Cukurova University. Retrieved from http://www.jstor.org/stable/1309424

Steduto, P., Hsiao, T. C., Raes, D., \& Fereres, E. (2009). AquaCrop-The FAO crop model to simulate yield response to water: I. Concepts and underlying principles. Agronomy Journal, 101. 426-437. https://doi.org/10.2134/agronj2008.0139s

Uehara, G., \& Tsuji, G. Y. (1998). Overview of IBSNAT. In: Tsuji, G. Y., Hoogenboom, G., Thornton, P. K. (Eds.). Understanding Options for Agricultural Production. Kluwer Academic Publishers, Dordrecht. The Netherlands, 1-7. https://doi.org/10.1007/978-94-017-3624-4

Villalobos, F. J., \& Fereres, E. (1990). Evaporation measurements beneath corn, cotton, and sunflower canopies. Agronomy Journal, 82, 1153-1159. https://doi.org/10.2134/agronj1990.00021962008200060026x

Whisler., F. D., Acock, B., Baker, D. N., Fye, R. E., Hodges, H. F., Lambert, J. R., Lemmon, H. E., \& McKinion, J. M., V. R. Reddy. (1986). Crop simulation models in agronomic systems. Advance in Agronomy, 40, 141208. https://doi.org/10.1016/S0065-2113(08)60282-5

\section{Copyrights}

Copyright for this article is retained by the author(s), with first publication rights granted to the journal.

This is an open-access article distributed under the terms and conditions of the Creative Commons Attribution license (http://creativecommons.org/licenses/by/4.0/). 